NBER WORKING PAPER SERIES

\title{
THE EFFECT OF CREDIT MARKET COMPETITION ON LENDING RELATIONSHIPS
}

\author{
Mitchell A. Petersen
}

Raghuram G. Rajan

Working Paper No. 4921

\section{NATIONAL BUREAU OF ECONOMIC RESEARCH \\ 1050 Massachusetts Avenue \\ Cambridge, MA 02138 \\ November 1994}

\begin{abstract}
We thank Alan Berger, Judith Chevalier, Constance Dunham, Mark Flannery, Michael Gibson, Anne Grøn, Oliver Hart, Steven Kaplan, Bob McDonald, George Pennacchi, Canice Prendergast, Rafael Repullo, Ivo Welch, Lawrence White, and John Wolken for valuable comments on a previous draft. We are again grateful to John Wolken for making a special effort to provide us with some of the data. The editor, Andrei Shleifer, and two anonymous referees made suggestions that improved the paper significantly. We also thank workshop participants at Brigham Young University, the University of California at Los Angeles, Camegie Mellon University, the Center for Economic Policy Research Conference on Financial Regulation at Toulouse, the Conference on Industrial Organization and Finance at San Sebastian, the University of Chicago, Columbia University, the Federal Reserve Board, the Federal Reserve Banks of Atlanta and Minneapolis, Harvard Business School, Indiana University, London School of Economics, Massachusetts Institute of Technology, Northwestem University, Southem Methodist University, Stanford University, Virginia Polytech, University of Wisconsin and the Utah Winter Finance Conference for their insights. This paper is part of NBER's research program in Corporate Finance. Any opinions expressed are those of the authors and not those of the National Bureau of Economic Research.
\end{abstract}

() 1994 by Mitchell A. Petersen and Raghuram G. Rajan. All rights reserved. Short sections of text, not to exceed two paragraphs, may be quoted without explicit permission provided that full credit, including (c) notice, is given to the source. 


\title{
THE EFFECT OF CREDIT MARKET \\ COMPETITION ON LENDING \\ RELATIONSHIPS
}

\begin{abstract}
This paper provides a simple model showing that the extent of competition in credit markets is important in determining the value of lending relationships. Creditors are more likely to finance credit constrained firms when credit markets are concentrated because it is easier for these creditors to internalize the benefits of assisting the firms. The model has implications about the availability and the price of credit as firms age in different markets. The paper offers evidence for these implications from small business data. It concludes with conjectures on the costs and benefits of liberalizing financial markets, as well as the timing of such reforms.
\end{abstract}

Mitchell A. Petersen

Kellogg School Northwestem University

Leverone Hall

Evanston, Il 60208
Raghuram G. Rajan Graduate School of Business University of Chicago 1101 East 58th Street Chicago, Il 60637 and NBER 
Is it possible for firms facing competitive credit markets to form strong ties to particular creditors? Does the benefit to a firm of forming such relationships diminish when credit markets get more competitive? There is a theoretical reason for believing that credit market competition may be inimical to the formation of mutually beneficial relationships between firms and specific creditors. When a firm is young or distressed, the potential for future cashflows from its projects may be high, while the actual cash it generates is low. When evaluating the credit-worthiness of the firm, a creditor should take into account the stream of future profits the firm may generate. When the credit market is competitive and crediors cannot hold equity claims, the lender cannot expect to share in the future surplus of the firm. She is constrained to break even on a period by period basis because she would drive away business if she charged a rate above the competitive one. Since uncertainty about a firm's prospects is high when the firm is young or distressed, creditors in a competitive market may be forced to charge a high interest rate until the uncertainty is resolved. This can be extremely distortionary to the firm's incentives and may, in fact, result in the firm not receiving credit at all. A monopolistic creditor, on the other hand, shares in the future surplus generated by the firm through the future rents she is able to extract. She can backload interest payments over time, subsidizing the firm when young or distressed and extracting rents later. Consequently, she may be more willing to offer credit than a similarly placed lender in a competitive market. In other words, credit market competition imposes constraints on the ability of the firm and creditor to intertemporally share surplus. This makes lending relationships less valuable to a firm because it cannot expect to get help when most in need.

The argument that relationships and competition are incompatible recurs in other sub-disciplines in economics.' For instance, labor economists claim that a firm is more reluctant to invest in training workers in a competitive labor market unless they post a bond, since workers can threaten to quit and demand a competitive salary once they are trained [Becker 1975]. While there is anecdotal evidence in the financial press suggesting this kind of phenomenon is a reality, there is little formal supporting evidence in the academic literature. ${ }^{2}$ This is partly because periods of increased competition are, in general, also accompanied by other changes which may make relationships less valuable. It is thus difficult to disentangle the effects. For example, Hoshi, Kashyap and Scharfstein [1990] document that 
high quality Japanese firms moved away from their banks when the domestic bond markets were liberalized. This movement may reflect the adverse effects of competition on relationships. Alternatively this movement may simply reflect a reshuffling of borrowing by firms that previously did not have access to public markets. The ideal test would examine the effects of competition on relationships in a situation where firms are not simultaneously faced with a change in the sources of capital available to them.

In this paper. we focus our analysis on small businesses in the United States. Such firms concentrate their external borrowing from banks [see Petersen and Rajan 1994] and therefore the confounding effect of the portfolio choice problem discussed above is minor. In different regions of the country, the degree of competition between banks varies, partly because of restrictions on bank entry and branching, partly because there is only so much banking business a local market can support. Thus, we can isolate the effects of competition on relationships in this sample.

In the next section, we present a simple model which highlights the distinction between competitive and concentrated credit markets. In section $I$, we describe the data and the empirical tests. We find that significantly more young firms obtain external financing in concentrated markets than in competitive markets. Underlying differences in firm quality across markets do not appear to explain the differential access to capital. As the theory suggests, creditors smooth interest rates intertemporally in more concentrated markets, which may explain why they are able to provide more finance. We conclude in section III with policy implications and suggestions for future research.

\section{The Model}

\section{A. Agents and lnvestment Opportunities}

Assume a risk neutral world where there are two types of agents looking for finance; good entrepreneurs and bad entrepreneurs. At date 0 , good entrepreneurs can choose either a safe project or a risky project. A safe project pays out $S_{1}$ at date 1 when amount $I_{0}$ is invested in it. Furthermore, when the project concludes the good entrepreneur will be able to invest $I_{i s}$ in another safe project which returns $S_{2}$. Alternatively, if the good entrepreneur chooses to gamble at date 0 , he can invest $I_{0}$ in the risky project. At date 1 , the risky project may succeed and pay out $R_{1}$ with probability $p$, or it may fail and pay 0 with probability (1-p). If it succeeds, he can invest $I_{1 R}$ in a safe project which pays $R_{2}$ at date 2 . 
In contrast to good entrepreneurs, the projects of bad entrepreneurs are doomed to fail and return nothing at date $1 .{ }^{3}$

We also make the following assumptions:

$$
\begin{gathered}
S_{2}+S_{1}-I_{I S}-I_{0}>0 . \\
p\left(R_{2}+R_{1}-I_{I R}\right)-I_{0}<0 . \\
p R_{2}=S_{2}>p I_{1 R}=I_{1 S} . \\
I_{1 S}>R_{1}>S_{1} .
\end{gathered}
$$

A.1 is simply that the safe project has positive net present value (NPV) in this risk neutral world, while A.2 implies the risky project has negative NPV. A.3 implies that the future positive NPV project has the same expected returns and investment, regardless of whether the safe or risky project is chosen at date 0. Finally, A.4 implies that the revenue from the date-0 project is insufficient to finance the project at date 1.

B. Finance.

Financial institutions are the only source of extermal finance in this market. For simplicity, we call these institutions banks. Agents know whether they are good or bad entrepreneurs. At date 0, banks only know that a fraction $\theta$ of the agents that demand finance are good entrepreneurs. Thus $\theta$ is a measure of the ex-ante credit quality of the agents. A number of studies suggest that a lending bank leams a lot about the kind of entrepreneur it is dealing with over the course of its relationship with the entrepreneur [for example, see the evidence in Lummer and McConnell 1989, and Petersen and Rajan 1994]. Therefore, we assume that at date 1 the bank becomes fully informed about the kind of agent with whom it is dealing. We also assume that for regulatory reasons banks can only hold debt claims, that is, contracts which require a fixed repayment by the borrower." Due to the difficulty of describing investments or the character of the entrepreneur to courts, contracts cannot be made contingent on the project taken or the type of agent. Finally, the bank can charge a rate such that its expected retum on loans is $M . M$ is a measure of the market power the bank has. In this risk neutral world where the risk 
free rate is zero, we get perfect competition in the credit market when $M$ equals 1 , while a bank has market power when $M$ is greater than 1 . For simplicity, we assume ${ }^{6}$

$$
\frac{S_{2}}{I_{1 s}}>M \geq 1
$$

The borrowing process is as follows: the agent (the good or bad entrepreneur) goes to a bank and indicates how much he wants to borrow and for what maturity. The bank responds by quoting an interest rate which will give it an expected return less than or equal to $M$. If no interest rate gives the bank an expected return greater than or equal to its cost of funds $(=1)$, it tums down the loan. In what follows, we determine how the quality of firms getting financed, and the amount they pay for credit over time, varies with the bank's market power.

C. Solving the Model.

This problem is a straightforward application of Diamond [1989] and Stiglitz and Weiss [1981].' At date 0 , good entrepreneurs cannot distinguish themselves from bad ones. Therefore, they can borrow only at a rate which compensates the bank for possible losses if the entrepreneur turns out to be bad. The higher interest rate can distort the entrepreneur's incentives and persuade him to choose the risky project. Thus adverse selection can cause moral hazard which in turn can lead to credit rationing.

To see this, first note that good entrepreneurs will try to reduce their own cost of borrowing by asking for terms that help expose the bad entrepreneurs. A bad entrepreneur will have no choice but to ask for the same terms at date 0 . Since bad entrepreneurs have no new projects at date 1 , the bank will not give them new money unless it has contracted to do so. Knowing this, good entrepreneurs will borrow as little as possible at date 0 , so they can take advantage of the lower rate at date 1 when the bad entrepreneurs have been exposed. Therefore, a good entrepreneur will seek to borrow only $I_{0}$ at date 0 . Without loss of generality, we assume that he proposes to repay amount $D_{1}$ at date 1 , after which he will contract a new loan for any subsequent project.'

If the good entrepreneur chooses the safe project at date 0 , at date 1 he must borrow 


$$
I_{1 S}-\left(S_{1}-D_{1}\right) \text {. }
$$

He can now borrow at the riskfree full-information rate $M .{ }^{9}$ If the good entrepreneur chooses the safe project at date 0 , he expects

$$
\max \left[S_{2}-M\left(I_{1 s}-\left(S_{1}-D_{1}\right)\right), 0\right] .
$$

Similarly, his expected profit if he chooses the risky project is

$$
\max \left\{p\left\{R_{2}-M\left[I_{I R}-\left(R_{1}-D_{1}\right)\right]\right\}, 0\right\} .
$$

Using assumptions A.3, A.4, and A.5, the good entrepreneur strictly prefers the safe project if

$$
\frac{S_{1}-p R_{1}}{1-p} \geq D_{1}
$$

For the bank to lend at date- 0 , two conditions must be satisfied. First the loan must be structured so that the good entrepreneur has the incentive to take the safe project. This is inequality (4). In addition, the bank must expect to recover its date-0 investment $\mathfrak{I}_{0}$. Taking into account the profit it can make by charging the maximum interest rate on loans made at date-1, this implies that the bank will lend only if

$$
D_{1} \geq \frac{I_{0}}{\theta M}-\frac{M-1}{M}\left(I_{15}-S_{1}\right) \text {. }
$$

Using (4) and (5), only entrepreneurs with credit quality greater than

$$
\theta^{c}(M)=\frac{I_{0}(1-p)}{M\left(S_{1}-p R_{1}\right)+(M-1)\left(I_{1 S}-S_{1}\right)(1-p)}
$$

will get financed.

Result 1. As the market power $M$ of the bank increases, firms with lower credit quality obtain finance.

The intuition is straightforward. As the market power of the bank increases, it can extract a larger share of the future surplus generated by the firm. This implicit equity stake in the firm enables it to set a lower interest rate for the initial project (compared to a more competitive situation). The surplus extracted in the future does not affect the firm's choice between projects (see equation (4)), but the lower 
initial rate give the firm an incentive to take the safe project. Consequently, firms of lower quality can be profitably financed.

The interest rate charged for funds lent at date 1 is $\mathrm{M}$. But at date 0 , the face value demanded, $D_{1}$ is bounded by:

$$
\min \left[\frac{I_{0} M}{\theta}, \frac{S_{1}-p R_{1}}{1-p}\right] \geq D_{1} \geq \frac{I_{0}}{\theta M}-\frac{M-1}{M}\left(l_{1 s}-S_{1}\right)
$$

The first argument of the minimum function is the limit set on the interest rate by the bank's market power, while the second is the limit set by moral hazard. The term after the second inequality is the bank's individual rationality condition. For the lowest quality firm financed by the bank with market power $M$, the binding upper limit on the interest rate is moral hazard. The lower binding constraint is the bank's individual rationality condition which depends on $M$. Therefore,

Result 2. The initial interest rate contracted by the lowest quality firm financed by a bank with market power $M$ is lower than it would be if such a firm were to be financed by a bank with market power $\mathbf{M}^{\prime}$ where $M>M^{\prime}$.

Finally, let $t$ be the ratio of the face value charged per dollar lent at date 1 to the face value charged per dollar lent at date 0 . This is the ratio of gross interest rates. Then for any initial credit quality $\theta$ and banks with market power $M$ and $M^{\prime}$ where $M>M^{\prime}$,

$$
t(M) \geq t\left(M^{\prime}\right)
$$

In a population of firms where $\theta$ has positive density everywhere on $[0,1]$,

$$
\text { Average }(\mathrm{t}(\mathrm{M}))>\operatorname{Average}\left(\mathrm{t}\left(\mathrm{M}^{\prime}\right)\right) \text {. }
$$

Result 3. On average, the relative decline in demanded repayments as the firm gets older is lower when the bank has more market power.

D. Caveats: Contractual Remedies.

Our main point, similar to Townsend [1982] and Gertler [1992], is that multi-period state contingent contracts allow for more efficient contracting than single or multiperiod fixed payoff contracts. 
In the environment we analyze, backloaded state contingent interest payments are less distortionary than frontloaded fixed interest payments. A creditor with market power can convert the latter into the former, which is why efficiency increases with creditor market power. There are obvious caveats.

We have abstracted from a variety of contracts which could commit the firm to sharing surplus with the lender, even in a competitive environment. For example, we have assumed that regulators do not allow creditors to hold equity claims. However, equity contracts may not be feasible even if allowed, since dividend payments are voluntary. Diamond [1984] and Hart and Moore [1989] specify environments where firm's management will never voluntarily part with cash. One way to force management to pay out cash in these environments is through debt contracts. Another way that we emphasize above is for a supplier to have market power in an essential input (credit) which enables it to extract cash from the firm. Thus the iniplicit equity stake that market power confers may be feasible even when explicit equity stakes are not.

The reader may wonder why long term debt contracts between the firm and the bank in the competitive environment cannot replicate the same payments over time as those determined by market power. The reason, quite simply, is that the payments due on the long term debt do not - and cannot vary with the project taken. The share of the surplus the bank gets by virtue of its market power does, however, vary. The firm has to pay nore to the bank if the risky (but ex-post profitable) project succeeds. This reduces the owner's incentive to shift risk. ${ }^{10}$ This also explains why contracts which require a high initial payment, and then commit the bank to relending at a lower-than-competitive rate will not work. These contracts have the effect of making the firm's payments conditional on the risky project succeeding lower and thus increase the firm's incentive to shift risk.

Within the class of debt contracts, however, complicated bonding contracts could commit the firm to sharing surplus. For example, the entrepreneur could commit to asking the bank for a loan at date 1 (giving it a 'first-right-of-refusal') at a pre-determined high rate." There may be practical difficulties in enforcing such a contract, primarily because the successful firm in a competitive credit market can easily find ways of borrowing without violating the letter of the 'first-right-of-refusal' contract. For instance, the entrepreneur could take out a personal loan from another source, collateralized by the shares 
of the firm, or sell equity and use the proceeds to repay the high priced loan. A contract ruling out such contingencies would be costly to write and difficult to enforce. Another problem is that having bonded the entrepreneur, the bank has no incentive to offer good service. Finally, it is possible that a populist legal system may refuse to enforce contracts which appear (ex post) to be extortionary. Thus bilateral opportunism or political realities may make these contracts impractical.

We have also abstracted from the distortions to the firm's investment incentives created by the bank's market power. Even if these are large, results 1, 2, and 3 will continue to hold so long as the bank can contractually dispose of its ability to extract future rents, as for example, by signing a loan commitment contract. The contract would need a 'material adverse change' clause allowing the bank to deny credit to bad entrepreneurs. While such contracts are observed, opportunism may again make them impractical.

In summary, the theory is ambiguous on whether the problem we have described can be effectively contracted around, though casual empiricism (see note 2) suggests it cannot. The test of whether it is important, however, must be an empirical one.

II. Data and Empirical Investigation

\section{A. Sample Description}

The data in this study are obtained from the National Survey of Small Business Finances. The survey was conducted in 1988-89 under the guidance of the Board of Governors of the Federal Reserve System and the US Small Business Administration. It targeted non-financial, non-farm small businesses which were in operation as of December, 1987. Financial data was collected only for the last fiscal year. The firms in the survey are small -- fewer than 500 employees. The sample was stratified by census region (Northeast, North Central, South, and West), urban/rural location (whether the firm was located in a MSA), and by employment size (less than 50 employees, 50-100 employees, more than 100 employees). The stratification was done to ensure that large and rural firms were represented in the sample. The response rate was seventy to eighty percent, depending upon the section of the questionnaire considered. ${ }^{12}$ 
There are 3404 firms in the sample, of which 1875 are corporations (including S corporations) and 1529 are partnerships or sole proprietorships. In the overall sample, the mean firm size in terms of book assets is $\$ 1.05$ million; the median size is $\$ 130,000$. The firms have mean sales of $\$ 2.6$ million and median sales of $\$ 300,000$. These companies are also fairly young, having spent a median of 10 years under their current ownership. In comparison, firms in the largest decile of NYSE stocks have been listed for a median of at least 33 years. Nearly 90 percent of these firms are owner managed, 12 percent are owned by women and 7 percent by minorities. Over 19 percent of the sample consists of firms in the botel and restaurant business. Another 13 percent are in building and construction, 7 percent manufacture intermediate products like chemicals, and 7 percent perform communication, electric, gas and sanitary services.

On average, firms in the sample have a debt to asset ratio of 0.33 . Of the debt, approximately 80 percent is from institutions while the rest consists of loans from the owners (in the cases of partnerships or corporations) and the owner's family. Banks account for 80 percent of the institutional lending, and non- bank financial institutions about 15 percent..$^{13}$ On average, trade credit financing is 10 percent of total assets, or about a third of the size of debt.

\section{B. Sources of Market Power}

In order to proceed further, we must determine proxies for the bank's market power. Note that nothing in our analysis requires the market power to be present ex ante. One possibility then is that the bank obtains market power ex post from the private information it obtains about the firm during the course of the lending relationship. The problem with this kind of local monopoly is that it would dissipate as the firm gets older and better known by the credit market. A second problem is that firms who find it hard to get credit are likely to offer their banks a local monopoly, making the choice endogenous. Finally, it is empirically hard to quantify the extent of information asymmetries about the firm between the inside lender and the outside credit market. 
Another source of market power is the spatial distribution of banks in the local market. Banks that are physically closer to the firm have lower costs of monitoring and transacting with the firm. These costs may be especially significant because the firms in our sample are sinall. If other banks are relatively far, close banks have considerable market power. The concentration of banks in the local geographical market is likely to be a proxy for how far competing lenders are likely to be from one other, and consequently how much market power any single lender has. Another way to think about this is that the search costs to a firm of finding a replacement lender who has the ability to deal with its specific needs are likely to be high when the local market has few lenders.

In what follows, we use the concentration of lenders in the local market as a measure of the lender's market power. Implicit in the analysis that follows is the following assumption: variations between local markets in the market power banks have because of their concentration in the local markets is much larger than variations between local markets in the amount of 'homemade' market power that firms voluntarily offer banks by giving them an information monopoly. If this were not true, our tests would be biased against finding any effect of spatial concentration on lending.

From the F.D.I.C. Summary of Deposit data, the SBA survey obtained the Herfindahl index of commercial bank deposit concentration for the county or Metropolitan Statistical Area where the firm is headquartered. The survey, however, reported only a broad categorization of competition in the local credit market. The survey reports whether the Herfindahl index is less than 0.1 , between 0.1 and 0.18 , or greater than 0.18 . We refer to the first category as the most competitive credit market, and the last category as the most concentrated credit market.

In what follows, we take the concentration of the market for deposits to be a proxy for the concentration of the market for credit. This would be a good approximation if the firms in our sample largely borrow from local markets because of the prohibitive informational and transactional costs of going outside. While there is evidence in prior work [see Hannan 1991] of this, we have independent 
confirmation that credit markets for small firms are local. ${ }^{14}$ The firms in our sample report the distance to their prinary financial institution. Over half the firms are within 2 miles of their primary institution. Ninety percent of the firms are within 15 miles of their primary institution.

If the Herfindahl index for deposits is a good proxy for competition in the loan market, we would expect to find greater solicitation of new business by financial institutions in more competitive markets. For firms less than ten years old, 32 percent of the firms in the most competitive market have been approached by at least one financial institution seeking new business in the past year. Only 26 percent of the firms in the least competitive market were solicited. The difference in solicitation rates is marginally significant at the 13 percent level. The difference in solicitation rates is greater, both economically and statistically, for the older firms. For firms which are more than ten years old the solicitation rates are 31 percent in the most concentrated market and 46 percent in the most competitive market. This difference (statistically significant at the one percent level) is, therefore, greatest for older firms where the model argues competition is most destructive to relationships.

Solicitation of new financial business from the firms in this sample is once again a local phenomenon. Of the firms which were solicited for new business, over half report that the soliciting financial institution is within 3 miles of the firm. All this suggests that the Herfindahl index of deposits is a good measure of credit market competition. Before examining the data, it may be useful to restate our empirical predictions in terms of this proxy.

\section{Empirical Implications}

The empirical predictions of the model are the following:

a. Provided the distribution of firm qualities is similar in all markets and provided that in at least one market some firms do not obtain finance, relatively more firms should be able to obtain credit from financial institutions in areas where credit markets are more concentrated. Furthermore, the average quality of firms obtaining finance should be lower as the credit market becomes more concentrated. 
b. Credit should be cheaper for the lowest quality firms in a concentrated credit market than if similar firms were to obtain credit in a more competitive market.

c. The cost of credit should fall faster as a firm ages in a competitive credit market than in a concentrated market.

\section{Credit Market Competision and Firm Quality}

The theory makes strong predictions about how borrowing will vary with fim age and market concentration. The sample we have is a cross section. However, by examining firms of different ages, we can make inferences about how borrowing changes over a firm's life. ${ }^{15}$ The first prediction is that if the quality distribution of firms applying for credit is the same in the different markets, firms of lower average quality (and, consequently, relatively more firms) will be financed in more concentrated markets. We first describe the differences in quality of all the firms in the different markets in Table 1. Thus this table is based on both those firms which borrow from institutional sources and those which do not.

We divide the data into two subsamples - firms younger than the median age of ten years and firms older than the median age. There are 296 firms in the most competitive credit markets and 2037 in the most concentrated markets. Firms in the two markets are approximately the same size as measured by the book value of total assets, with the median size of young firms being $\$ 102,000$ and $\$ 103,000$. There is greater disparity between the mean size of young firms $(\$ 863,000$ in competitive markets and $\$ 569,000$ in concentrated ones) but the difference is not statistically significant. Firms in the middle category (Herfindahl index between 0.10 and 0.18 ) are larger but not statistically so.

The young firms in the more competitive credit markets are somewhat more profitable. The ratio of gross profits (revenues less cost of goods sold) to assets is 2.78 in the competitive market and 1.88 in the most concentrated markets. The medians differ in similar ways. Moving on to operating profit ratios, again firms in the most competitive market are more profitable (a mean ratio of 1.14 versus 0.63 ), although the difference is no longer statistically different. The median ratios are even closer $(0.17$ versus 
0.15). The rates of sales growth do not differ much across the markets (see Table I).

A firm's access to capital may depend upon the tangibility and/or the liquidity of its assets. The industry the firm is in should be a good proxy for this. As is typical for small firms, a significant fraction of our sample are in the retail trade and services industry. However, over ten percent of the firms are in construction and another ten percent of the firms are in manufacturing. The distribution of firms across industries is very similar in the most concentrated and the most competitive markets (see Figure I). The most competitive markets have relatively fewer firms in services and somewhat more in wholesale trade but the fractions of firms in the other industries are roughly equal across markets. In sum, the quality of firms in the most competitive market appears as good if not better than the quality of firms in the most concentrated market. Our results should be biased -- if at all - towards finding more institutional financing in competitive areas. ${ }^{16}$

Finally, it is useful to ask whether the concentration of credit markets is correlated with the region of the country. This is important to ensure that we do not pick up the effects of a regional shock in what follows. A cross tabulation of the region in which the firm is located (Northeast, North Central, South, and West) and the level of competition in the local credit market (we do not report this in a table) indicates that firms in the southern and western regions are under-represented in the most competitive market and over-represented in the most concentrated markets. However, the magnitude of these differences is small. The correlations between the Herfindahl index and each of the four region durmies ranges from -0.12 to 0.15 .

\section{E. Credit Market Competition and the Availability of Finance}

The theory in the previous section suggests that young firms are more likely to receive institutional finance in a concentrated credit market than in competitive one. Among the youngest half of our sample (firms which are less than ten years old), the firms in the most concentrated market are 
more likely to obtain capital from institutional sources (see Table II). Sixty five percent of the firms in the most concentrated market have institutional debt compared to only 55 percent of firms in the most competitive market, with the difference being significant at the 1 percent level. Ten year old firms may not be considered young. As Table II demonstrates, the difference in institutional financing is most extreme among firms which are four years old or less. Forty eight percent of such firms in the most competitive market have institutional debt compared to 65 percent of the firms in the most concentrated market. The difference is again statistically significant at the one percent level. The potential effects of a survival bias (see section II $\mathrm{H}$ ) on our results will be smallest for the youngest firms in our sample. Yet in this part of our sample, the differential access to capital is the largest.

As firms grow older, the difference in the fraction of firms being financed in the two markets vanishes. For firms that are older than 10 years, approximately 61 percent use institutional finance, irrespective of the stale of competition in credit markets (see Table II).

The differences in the fraction of young firms with institutional debt does not arise because firms in a concentrated market borrow less. The instinutional debt to assets ratio for young firms which have institutional debt is slightly higher in concentrated markets -0.42 compared to 0.35 . For firms older than ten years, the numbers are reversed. The institutional debt to asset ratio is 0.43 in the most competitive market and only 0.35 in the most concentrated market. As furms get older in the concentrated market, they borrow smaller amounts from these outside sources and rely more on equity and internal funds. This is consistent with our model. If borrowers in such markets are offered lower-than-competitive rates when young, this subsidy musi be made up by charging them a higher-than-competitive rate when old. This will encourage them, at the margin, to substitute away from external borrowing when old.

In our discussion so far, we have implicitly assumed that the amount of institutional debt used is the amount of debt available to the firm. Such an assumption is, perhaps, defensible for the youngest firms which may have few internal sources of funds and many lucrative investment opportunities. For 
older firms it is less clear whether the amount of institutional debt is supply constrained (creditors do not want to lend more) or demand constrained (borrowers prefer internal sources). That older firms borrow less in concentrated markets does not necessarily indicate that these firms are more supply constrained. In order to explore this issue further, we turn to a better measure of credit availability.

\section{F. An Alternative Measure of Credit Availability}

If financial institutions limit the credit extended to a firm, the firm will borrow from more expensive non-institutional sources as long as the returns from its investments exceed the cost of funds from those sources. Correcting for investment opportunities, the amount of expensive borrowing should be a measure of how much the firm is rationed by the (cheaper) institutional sources - provided the following conditions hold. First, the marginal cost of borrowing from the non-institutional source must exceed the marginal cost of available institutional credit. If it did not, the firm would turn to noninstitutional sources of credit first. Second, the cost of borrowing from the non-institutional source should be relatively similar for firms within an identifiable class.

Most of the firms in our sample are offered trade credit - short term financing which some suppliers provide with their goods and services. As reported in Table III, the median firm in all three kinds of markets obtains 90 percent of its purchases on credit. Another measure of the firm's use of trade credit is its Days Payable Outstanding (DPO) - which is defined as 365 times the firm's accounts payables divided by its cost of goods sold. The median firm's DPO is about 15 days across the markets. We have data on the percentage of discounts for early payment which are taken by each firm. In general, discounts for early payment are substantial and are meant to encourage the firm to pay on time. For example, firms in the retail business refer to terms as the 10-2-30 rule. This is a discount of 2 percent if the bill is paid within 10 days and the full amount if paid in $\mathbf{3 0}$ days. A firm that passes up the discount and the bill when due pays an annualized rate of 44.6 percent, far higher than the highest interest rate charged to firms in our sample." 
Previous work indicates that discount terms are not specific to a firm, but are common practice throughout the industry [Elliehausen and Wolken, 1992. Petersen and Rajan, 1994]. Furthermore, although the decision to offer trade credit depends upon the firm's quality, the decision by trade creditors to offer early payment discounts does not. Approximately thirty-three percent of trade credits are accompanied by early payment discounts. This number does not vary with firm size or firm age. As these discounts and penalties are substantial and are industry- not firm-specific, the fraction of trade discounts not taken is a good proxy for the costly non-institutional credit source. ${ }^{19}$

By this measure, fewer firms appear to be credit constrained in concentrated markets than in competitive markets (see Table III). Only 19 percent of firms in concentrated markets take fewer than 10 percent of offered discounts, compared to 29 percent in the middle market and 33 percent in the most competitive market. Conversely, over 59 percent of firms in the most concentrated market take more than 90 percent of offered discounts, compared to 52 percent in the middle market and 50 percent in the most competitive market.

Clearly, these monotonic relationships are only suggestive since they do not control for firm quality or other factors which may be correlated with credit market concentration. To test the robustness of these results, we regress the percentage of trade discounts taken against measures of the firm's investment opportunities, its cashflow, measures of the strength of its lending relationships, and the state of competition in credit markets. Firms which take a larger percent of their early payment discounts should be less credit constrained. We include three measures of the firm's investment opportunities. Investment opportunities may depend on the firm's size - the book value of its assets - and the log of the firm's age (younger firms may have better opportunities). Since investment opportunities depend on the industry the firm is in, seven industry dummies are included as explanatory variables. Clearly, all these variables may also proxy for the credit quality of the firm.

The firm's internal cash flow is accounted for by including income after interest normalized by 
the firm's book value of assets. We include a dummy for whether the furm is a corporation or not, because credit rationing should be greater for firms with limited liability. An owner managed firm has a greater incentive to take on risky projects if it has limited liability. Petersen and Rajan [1994] find that the strength of relationships between firms and financial institutions are an important determinant of whether firms rely on trade credit financing. This is why we include the measures of relationships: the $\log$ of the length of the longest relationship the firm has had with a financial institution, the fraction of borrowing that comes from institutions that provide at least one significant financial service to the firm, and the number of institutions that account for more than 10 percent of the firm's borrowing.

Finally, we include an indicator if the firm is in the most concentrated credit market. If availability does not depend on the concentration of the credit market, the coefficient for this term should be zero.

The dependent variable in the regression should be the desired fraction of early payment discounts which the firm would like to take. Firms that are rationed by financial institutions will choose to borrow from trade creditors at the rates implicit in foregoing the early payment discount. In fact, they may wish to borrow more than is offered through their trade credits. Thus the desired percentage may be less than zero. Since firms cannot take less than 0 or more than 100 percent of the carly payment discounts, the observed dependent variable is censored at 0 and 100 percent. In our sample, 60 percent of the firms are censored at 0 or 100 . Estimating the model with ordinary least squares ignores this censoring, and consequently, estimates will be biased toward zero. We, therefore, estimate a tobit regression with two sided limits.

In Table IV we examine the determinants of the percent of offered discounts taken by the firm. The estimates in column I indicate that the investment and cashflow variables have the predicted sign. Older and larger firms have fewer investment opportunities and so can take more trade discounts by paying on time. If age and size proxy for credit quality, this result suggests that higher quality firms are 
less likely to be credit rationed. Profitable firms have more internal cash so they are less likely to use trade credit as a means of long term borrowing. Again, this may be a proxy for quality. Finally, because of their limited liability, corporations are more likely to take risky projects, which explains why they are more likely to be rationed.

The relationship variables also have the predicted signs. A long relationship with a financial institution increases the percentage of discounts taken, even holding the age of the firm constant. Borrowing a greater fraction from lenders who provide the firm services has a similar effect, although this effect is not statistically significant. Borrowing from multiple institutions makes relationships more diffused and increases the degree to which the firm is credit constrained.

The degree of concentration in financial markets enters in an economically and statistically significant way. A firm in the most concentrated market takes 17 percentage points more trade credit discounts than do firms in most competitive credit markets $(t=2.9)$. This coefficient is forty percent of standard deviation of the percentage of discounts taken. In other words, after controlling for observable measures of credit demand and credit worthiness, we find firms in the most concentrated credit market are the least credit rationed.

An alternative explanation for our results is that credit constraints are less binding in small towns. Information about small businesses and their managers may be more available, or the pressure to repay debts may be greater, in rural areas. This should make credit rationing less severe. The correlation between our measure of credit market concentration and whether the firm is in a Metropolitan Statistical Area (MSA) is 0.44 . The estimated coefficient for the indicator variable for MSA in Table IV column I is less than half that for the concentration indicator $(\beta=-7.4)$ and statistically small $(t=1.4)$. However, when we drop the indicator for SMSA from the estimation, the coefficient on the concentration indicator increases from 16.5 to 19.7. Thus the rural/urban divide has some effect in the predicted direction, but this does not account for the influence of concentration. 
Another possibility is that the Herfindahl index is correlated with whether the firm is located in a state with a unit banking law. These states may have been especially affected by regional shocks - for instance, to the oil or natural resources industries - which in turn may have affected the entire regional economy. ${ }^{19}$ Thus firms in competitive markets may be credit constrained not because the markets are competitive, but because they are in states affected by adverse regional shocks. The empirical facts are not, however, consistent with this alternative hypothesis. First, if the firms in competitive markets have been affected by regional shocks, then their profitability and sales should be affected by the shock. As is apparent in Table I, the firms in competitive markets have profit to assets ratios which are at least as large if not larger than the firms in the most concentrated markets. Sales growth for firms in the most concentrated market is the same as sales growth for firms in the most competitive market. Thus sales and profits of firms in these markets do not reflect adverse shocks.

A more direct test of this hypothesis is to control for the banking laws of the state in which each firm is located. This is done in the second column of Table IV. Firms in unit banking states are less credit constrained $(\beta=9.3)$, although this coefficient is not statistically different from zero $(t=0.9)$. More imporantly, including a control for firms in unit banking states bas only a marginal effect on the coefficient of the indicator variable for concentration. This coefficient actually rises from 16.5 to 17.1 . Given the low correlation between the firm being located in a unit banking states and it being located in the most concentrated market $(\rho=-0.07)$, this finding is not surprising. ${ }^{20}$

The evidence presented so far suggests that controlling for the observable measures of quality, firms in more concentrated credit markets are less credit constrained. The remaining portion of this section adds additional controls to the model to test the robustness of this finding and the accuracy of our assumptions. First, we have assumed that the firm's investment opportunities do not differ systematically with the concentration of the credit markets. The potential problem is that firms in more competitive credit markets may have greater investment opportunities and thus take fewer early payment discounts. 
As an additional control for investment opportunities we include the firm's sales growth, since intuitively firms with higher sales growth should also have more investment opportunities. The data, however, does not indicate that concentration proxies for differences in investment opportunities. The coefficient on the firm's sales growth is small and has the wrong sign. Firms with higher sales growth are slightly less credit constrained. In addition, the effect on the concentration coefficient is small. The coefficient on the Herfindahl index rises from 16.5 to 16.8 (see Table IV - column III).

An alternative way of correcting for differences in industry profits, investment opportunities, and terms of trade credit in the industry is to include more detailed industry dummies. Instead of the seven industry dummies - representing one-digit S.I.C. codes - we include indicators for all two digit S.I.C. industries that account for more than l percent of the sample. We lose a number of degrees of freedom, and the concentration coefficient falls slightly to 14.5 (estimates not reported in table) but is still statistically significant $(t=2.5)$.

The model in the previous section argues that the greater the lender's market power, the less credit constrained the borrower will be. So far, we have focussed on the differences between the most concentrated market and the other markets. But as Table II indicates, there seems to be a monotonic increase in the fraction of firms getting credit as we move across the three broad ranges for the Herfindahl. To test the monotonicity of this relationships in the trade credit regression, we add an additional dummy variable for the firms in the most competitive market. These estimates are reported in column IV of Table IV.

According to the model, the coefficient on the most competitive market dummy should be negative since these firms should be more credit constrained than the intermediate market which is the base. Instead the coefficient is positive. However, the coefficient is not statistically different from zero $(t=1.1)$. Since our controls for relationships, such as the relationship length, depend upon the concentration of the credit market, we may be double counting. Interestingly, when we drop the 
relationship variables, the coefficient on the most competitive market drops to $3.7(t=0.4)$. Thus we cannot distinguish the most competitive market from the middle market, although we can distinguish the most concentrated market from the other two.

Our inability to distinguish the estimates may be because the difference in credit availability between markets diminishes as firms become older and more established. Unfortunately the data are not discriminating enough for us to detect this phenomenon in the trade credit regressions. When we include both dummy variable for different levels of credit market competition and interactions with the firm's age (estimates not reported), the standard errors grow dramatically. However, we report means and medians of the percent of early payment discounts taken by firms in different markets in Table V. As expected from the model, we find that for young firms (age less than the median), the median discounts taken is relared to the concentration of the market. The difference in medians is 10 percent higher in the middle market than in the most competitive market, and 30 percent higher in the most concentrated market than in the middle market. For the old firms, these differences vanish. The means follow a similar pattern, and unlike the medians, the differences in means are statistically significant.21

To summarize, we find that the amount firms borrow from financial institutions tends to increase with the concentration of the credit markets. When we examine a measure of availability of institutional finance rather than actual usage, we find that young firms appear less constrained in more concentrated markets. Regression estimates suggest that firms in the most concentrated market appear to be significantly less credit constrained than firms in the other two markets. The evidence is largely consistent with the theory proposed in section I. However to establish that the greater availability is because lenders in concentrated credit markets intertemporally smoothing interest rates, we now turn to analyze interest rates.

G. Cost of Capital Differences in Competitive and Concentrated Markets

Our model suggests that in markets where lenders have market power, they should charge a 
lower-than-competitive interest rate early in a firm's life, when problems of moral hazard and adverse selection are large. Later, they will compensate by demanding an interest rate above the competitive rate. For this reason, we expect the interest rate to fall more rapidly in competitive markets.

To test these predictions, we examine a subset of 1277 firms for which we have the interest rate charged on the firm's most recent loan. This is described in Table VI. The average interest rate is calculated for both the young (age less than 10 years) and old firms in the most concentrated and most competitive markets. Young firms pay higher average rates than old firms, but the pace at which the rate declines is larger in the most competitive market. In the most concentrated market the young firms pay 34 basis points more than old firms $(t=2.17)$; however in the most competitive market this difference is 86 basis points. Notice that the interest rate starts higher in the competitive market and ends lower. This result is inconsistent with the argument that market concentration is a proxy for town size and the associated access to information. If this were true, rates should be uniformly lower in the concentrated market, not just for the youngest firms.

These results are only suggestive. We have made no adjustment for observable firm quality. According to the model in the previous section, lenders will lend money, on average, to lower quality firms in the more concentrated markets. Thus the difference in rates above between young fims in competitive and concentrated markets may understate the difference we should expect to find once we control for observable measures of quality.

To control for other factors which affect the interest rate a firm pays and to test the robustness of our findings, we estimate the loan rate as a function of the log of the firm's age and controls for observable firm and loan characteristics. In the regression results below we use the prime rate to control for changes in the underlying cost of capital. The prime rate includes both the risk free rate as well as a default premium for the bank's best customers. Since these small businesses are not the bank's best customers, they pay an additional default premium. We control for aggregate variations in this premium 
by including the difference between yield on corporate bonds rated BAA and the yield on ten year government bonds. We also include a term premium, defined as the yield on a government bond of the same maturity as the loan minus the treasury bill yield, to account for interest rate differences across different loan maturities. For floating rate loans this variable is set to zero.

To control for variation in the loan rate due to the characteristics of the loan we include dummies for whether it is a floating rate loan, for the kind of collateral offered, and for the type of lender making the loan. To control for variation in the loan rate due to the characteristics of the firm we include the firm's size (book value of assets), dummies for the firm's industry, and whether the firm is incorporated. We also include the relationship variables used by Petersen and Rajan [1994].

Since we expect firm age to have a different effect in competitive and concentrated markets, we estimate different age intercepts and slopes for each level of market concentration. The intercept measures the difference between a loan in the most concentrated and the most competitive market, when the firm is new. As Table VII shows, firms in the most concentrated market start out at an interest rate which is 129 basis points lower than in the most competitive market. Interest rates drop as the firm grows older, consistent with Dianiond's [1989] notion that survival is a signal about the true quality of the borrower. The rate at which the loan rates dop, however, differs significantly across markets. The coefficient on age is over four times larger in the most competitive markets (Herfindahl index $<0.10$ ) than in the most concentrated markets (Herfindahl index $>0.18$ ). As a firm ages from new to the median age of ten years. its interest rate drops by 167 basis points in a competitive market. The interest rate drops only 36 basis points for firms in the most concentrated markets (see Figure II). In addition to being large in magnitudes, the difference in the slopes are also statistically significant $(t=2.0)$. The fact that the slope of interest rates with age is flatter in concentrated markets is a direct implication of the our model. ${ }^{n}$

While it is interesting that interest rates start out lower for firms in the most concentrated area, it is not necessarily a prediction of our theory. Our theory only suggests that new firms of the lowest 
quality should obtain a lower loan rate in a concentrated market, it has nothing to say about the rate charged to the average new firm. The average loan rate in the concentrated market will be affected by both a higher markup charged to higher quality new firms $(M>1)$ - which will tend to raise the average interest rate - and lower than competitive rates charged to low quality young firms - which will reduce it. The average effect depends on the distribution of firms. This may explain why the intercept is not monotonic, being even lower for firms in markets of intermediate concentration than in the most concentrated area $(-1.70$ and -1.29$)$. But the slope coefficient in the intermediate market is not statistically or economically different from that for the most concentrated area $(-0.135$ vs. -0.154$)$.

As discussed in section II.F., market concentration is correlated with the urban/rural location of the firm. As further evidence that concentration is not a proxy for the location of the firm, we re-estimate our rate regressions allowing the slopes to differ for firms in urban and rural locations rather than for firms in concentrated and competitive markets. Based on the results in the second column of Table VII, the rural/urban difference does not drive the results on concentration. The interest rate charged does fall with age, however, the rate of decline is very similar in rural and in urban markets. For firms in an MSA the coefficient on age is -0.240 ; for rural firms the coefficient is -0.154 . The difference is not statistically significant $(t=0.6)$. Instead of market concentration being a proxy for the location of the firm (urban versus rural), the location of the firm is a proxy for market concentration.

Finilly, we test for the effect of state banking laws on the rate. The inclusion of an indicator for unit banking states has little effect on the coefficient on age or the intercept in any of the markets (see Table VII column III). Our results appear to be robust; controlling for other firm and loan factors, the loan rates in the concentrated market start lower but do not fall as much with firm age as loan rates in the competitive market (see Figure-11).

\section{H. Survivorship Biases in Different Credit Markets}

Interest rates slope downwards with firm age because good entrepreneurs survive while bad 
entrepreneurs go under. It is, however, important for us to ask if differences in the survival rate of bad entrepreneurs across markets could be responsible for the differences in estimated slopes across markets.

We assume in the model that bad types are all weeded out after one period. This ensures that the quality of surviving firms at date- 1 is the same in all markets, even though lower quality firms are started in the concentrated market. An alternative possibility is that the greater availability of finance for low quality firms could make the attrition rate lower for bad firms in concentrated markets. Yet another possibility is that competition in the product markets may be fiercer in areas with competitive loan markets. Under the assumption that age proxies for unobservable elements of firm quality, we would find demanded interest rates falt less with firm age in concentrated markets.

Clearly, unobservable quality should be correlated with observable proxies for quality. Table I provides little evidence that surviving old firms in concentrated credit markets are of lower quality. The mean and median firm size and growth rates for old firms (firms greater than 10 years) is about the same in both competitive and concentrated markets though median profits - but not mean profits -- are larger in the competitive markets. It is possible that most low quality firms have been weeded in all markets by the time firms are 10 years old. If differences in attrition rates are to explain the relative slopes of the interest rate with age, much of the difference in attrition rates should occur when firms are very young (because we have empirically documented a much steeper decline in interest rates with firm age for very young firms in competitive areas). We subdivide young firms into the very young (age less than 5 years) and the not so young (age greater than 5 but less than 10 years). If differential attrition takes place when firms are very young, the not so young firms should look much healthier in the competitive market. The evidence (not reported in table) does not support this. The not so young firms in the middle market dominate or tie with similar firms in competitive markets on all four dimensions of quality (median size, gross profits, net profits, and sales growth). The not so young firms in the concentrated market are the same size as those in competitive markets, have higher net profits but lower gross profits and sales 
growth. None of these differences are significant at standard levels. ${ }^{23}$ Interestingly, size, which is the variable least likely to be mismeasured, is approximately the same at $\$ 121,000$ across the markets. While we hesitate to dismiss differential survivorship as an explanation for the different slopes - note, however, that it would not explain the differences in intercepts or the differences in availability - we do not find evidence supporting it.

\section{Discussion}

Young tirms in concentrated markets receive more institutional finance than do similar firms in competitive markets. As firms get old, the difference in the relative firms borrowing from institutions disappears. Young firms who get institutional loans are more indebted in concentrated markets than in competitive markets but this pattern reverses for older firms. Creditors seem to smooth interest rates over the life cycle of the firm in a concentrated market, charging a lower-than-competitive one when the firm is young and a higher-than-competitive rate when the firm is old. We now discuss possible interpretations of this result.

The results do not arise because firms in concentrated credit markets are very different from firms in competitive credit markets, since they persist even after we correct for the obvious firm and industry characteristics (see Tables IV and VII). In fact the sample of all firms in the different markets do not look very different (Table I). One possible explanation of our results is that banks in concentrated markets misprice their loans. But our results require them to be inconsistent in their mispricing, being excessively eager to lend to young, little known firms and excessively cautious in lending to older, established firms. While we cannot rule out this possibility, it is hard to think of plausible assumptions that would lead to such behavior. It is also possible that concentration is a proxy for other factors. It may be easier for snall firms in rural markets to get credit, simply because lenders have better information about borrowers in a small community where news, and gossip, travel fast. The problem with this explanation is simply that ease of information acquisition cannot be the whole story, else firms in concentrated markets should enjoy 
uniformly lower rates independent of age. In addition, the results are not altered when we control directly for whether the firm is located in a rural area.

We think the most plausible explanation is the theoretical one provided in section I. Creditors in concentrated markets have an assurance of obtaining future surplus from the firm and consequently accept lower returns up front. This enables many more firms to be financed before the nominal interest rate rises to the point where the possibility of moral hazard forces the lender to cut off credit. Of course, banks in concentrated markets lend with the expectation that they will recover the initial subsidy via higher interest rates in the future. This explains why the surviving, older firms in concentrated markets pay higher nominal rates than surviving older firms in competitive markets. Finally, the natural response of older firms who have few investment opportunities and are faced with higher interest rates is to use less external finance. This would explain why older firms in concentrated markets rely on internal opposed to institutional finance.

There is a legitimate concern whether our findings are applicable to larger enterprises. The economic forces we have identified, however, are not special to small enterprises. While the main source of competition for a bank in the sample we examine is other banks, competition to fulfill the financing requirements of larger firms comes from arm's-length sources like the commercial paper, equity, and bond markets. The relative cost of borrowing from banks rather than markets is likely to be high for large, reputable firms [see Diamond, 1991, Rajan, 1992]. It is even less likely that banks will be able to retain the business of successful firms when competition is from arm's-length markets than when competition is from other banks. Therefore, a natural consequence of the opening up of arm's-length credit markets is that lending relationships deteriorate, young firms are more liquidity constrained, and banks are less willing to help their clients in financial distress. ${ }^{24}$

It is, however, easy to draw the wrong welfare implication from these findings. The absence of credit-market competition is only one way firms and creditors can share future surplus, and it is not 
costless. The higher interest rate paid by successful survivor firms in concentrated markets can be distortionary and force them to reduce their reliance on external funds. This may affect their investment and reduce their rate of growth. There are contractual ways of ensuring bilateral commitment between lender and borrower which may be less costly. For example, in addition to lending, the creditor could take an equity stake in the young or distressed firm. ${ }^{25}$ While an equity claim would give the lender a share in the future surplus generated by the firm, explicit contracts (as opposed to implicit contracts enforced by the environment) have the added advantage of being voluntary so that firms whose incentives would be excessively distorted by sharing future surplus would not enter into them.

Of course, it may not always be possible to promote relationships via contracts. Equity contracts may not commit entrepreneurs to a credible payout policy. Creditors may not want to hold equity because it makes them 'soft' when dealing with errant borrowers [see Dewatripont and Tirole 1992]. Owners may be reluctant to give the bank equity because they may fear too much bank interference. A bank may be less inclined to monitor the firm on behalf of, and act in the interest of, other fixed claim holders (like employees and other creditors) if it also holds equity claims. A political concern is that banks may effectively bypass anti-trust laws if they build substantial equity holdings in similar companies. Clearly, it is an empirical matter whether these costs outweigh the benefits from stronger relationships, and our study has nothing to say about this.

It is interesting to speculate on the policy implications if the only way to promote relationships is by restricting credit-market competition. In the early stage of a country's economic growth when there are comparatively few established firms, the availability of finance is most important. It may be least inefficient to restrict inter-bank competition in order to achieve this. ${ }^{26}$ But as many firms become established, the distortionary price for credit becomes a more important source of inefficiency. At this point, de-regulation and introducing more inter-bank competition, as well as opening up arm's-length markets may make the most economic sense. ${ }^{27}$ Clearly, the period before an anticipated liberalization 
will be troubled as relationships breakdown before the benefits of competition kick in. But this may be unavoidable for an economy that wants to optimize the trade-off between the availability and the price of credit.

The general point the paper makes is that competition and long-term relationships are not necessarily compatible, whether the markets being analyzed are labor or capital markets. Reformers in relationship-based economies are not always right (as suggested by Mayer [1988]) if they think that adding a dose of competition to their systems will necessarily make it better off. Conversely, it may be equally wrong to expect firm-creditor or firm-worker relationships to be as strong or valuable in the competitive U.S. markets as in the cartelized markets elsewhere.

Northwestern University

University of Chicago 


\section{References}

Becker. Gary S. Human Capilal (Chicago, IL: University of Chicago Press, 1975).

Berger, Allen, and Gregory Udell, "Small Firms, Commercial Lines of Credit, and Collateral," Board of Governors of the Federal Reserve System, 1992.

Dewatripont, Mathias, and Jean Tirole, "A Theory of Debt and Equity: Diversity of Securities and ManagerShareholder Congruence," C.E.P.R. Working Paper, 1992.

Diamond, Douglas, "Finnncial Intermediation and Delegated Monitoring," Review of Economic Studies, LI (1984), 393-414.

"Reputation Acquisition in Debt Markets," Journal of Political Economy, XCVII (1989), 828-861. 738.

"Debt Maturity Siructure and Liquidity Risk," Quarterly Joumal of Economics, CV1 (1991), 709-

Dunn and Bradsireet, Handbook of Credil Terms (1970).

Elliehausen, Gregory, and John Wolken, "The Use of Trade Credit by Small Businesses" Board of Governors of the Federal Reserve (1992).

Fischer, Klaus, "Hausbankbeziehungen als Instrument der Bindungzwischen Banken und Unternehmen", Ph.D. Thesis, Universitat Bonn, (1990).

Gerter, Mark, "Financial Capacity and Output Fluctuations in an Economy with Multi-Period Financial Relationships," Review of Economic Studies, LIX (1992), 455-472.

Hannan. Timothy, "Bank Commercial Loan Markets and the Role of Market Structure: Evidence from Surveys of Commercial Lending," Journal of Banking and Finance, XV (1991), 133-149.

Han, Oliver, and John Moore, "Default and Renegotiation: A Dynamic Model of Debt," Massachusetts Institute of Technology Working Paper, 1989.

Hoshi, Takeo. Anil Kashyap, and David Scharfstein, "Bank Monitoring and Investment: Evidence from the Changing Structure of Japanese Corporate Banking Relationships, " in R. Glenn Hubbard, ed., Asymmetric Information, Corporate Finance and Investment, (Chicago, IL: University of Chicago Press, 1990).

James, Christopher, "Some Evidence on the Uniqueness of Bank Laans," Joumal of Financial Economics, XIX (1987), 217-235.

James, Christopher, and Peggy Wier, "Borrowing Relationships, Intermediation, and the Cost of Issuing Public Securities," Journal of Financial Economics, XXVII (1990), 149-171.

Kaplan, Steven, and Bernadette Alcamo Minton, "Outside Intervention in Japanese Companies: Its Determinants and Its Implications for Managers". University of Chicago, 1992. 
Lummer, Scott, and John McConnell, "Further Evidence on the Bank Lending Process and the Capital Market Response to Bank Loan Agreements," Journal of Financial Economics, XXV (1989), 99-122.

Macrae, Norman, "Sweaty Brows Slippery Fingers," The Economist, (September 8, 1990), 21-24.

Meerschwam, David, Breaking financial boundaries: Global capital, national de-regulation and financial services firms (Cambridge, MA: Harvard Business School Press, 1991).

Mayer. Colin, "New Issues in Corporate Finance," European Economic Review, XXXII (1988), 1167-1189.firms (Cambridge, MA: Harvard Business School Press, 1991).

Mian, Shehzad, and Clifford Smith, "Accounts Receivable Management Policy: Theory and Evidence," Journal of Finance, XLVII (1992), 169-200.

Myers, Stewart, "Determinants of Corporate Borrowing," Journal of Financial Economics, V (1977), 147-175.

Petersen, Mitchell, and Raghuram Rajan, "The Benefits of Lending Relationships: Evidence from Small Business Data," Journal of Finance, XLIX (1994), 3-37.

Rijjan, Ragliuram, "Insiders and Outsiders: The Choice between Informed and Arm's Length Debt," Journal of Finance, XLVII (1992), 1367-1400.

Stiglitz. Joseph, and Andrew Weiss. "Credit Rationing in Markets with Imperfect Information," American Economic Review, LXXI (1981), 393-410.

Thakor, Anjan, and Richard Shockley, "Information Content of Commitments to Lend in the Future: Theory and Evidence on the Gains from Relationship Banking," Indiana University Discussion Paper, No S23, 1992. Townsend, Rober, "Optimal Multiperiod Contracts and the Gain from Enduring Relationships," Journal of
Political Econonry, XC (1982), 1166-1186. 
1. The basic argument dates back, at least, to Schumpeter who proposed that a monopolistic economy offers better incentives for innovation because an inventor can recoup her investment in R\&D through future rents. Mayer [1988] introduces this problem to the finance literature discussing the general inability of firms and creditors to commit to a mutually beneficial course of action. Fischer [1990] models the problem posed by competitive credit markets formally and suggests that a way for a firm to commit to sharing future rents with the bank is to give the latter an informational monopoly. Rajan [1992] argues that even the bank's information monopoly may be insufficient to bind the firm when competition comes from arm's length markets.

2. The Economist [November 13, 1993, p 84] describes the problem as follows:

"...banks remain unable to charge prices that reflect the high risks of lending to small companies. Startups are especially risky; not only do plenty of them fail, but those that succeed tend to exploit their success by refinancing their debt more cheaply.... One big British bank reckons that to make a profit today it would have to double interest margins on its loans, from an average of three percentage points over the base rate. That might provoke the government to intervene.

So banks are looking for other ways to boost returns from borrowers that succeed. Some, such as Midland, would like to take small equity stakes. Others talk of introducing a clause into loan agreements that would give the bank a one-off fee if a borrower wanted to refinance its debt. Customers are understandably unkeen."

3. Bad entrepreneurs are the incompetent, the lazy, and the dishonest in the population of potential entrepreneurs. The incompetent invest in the wrong projects and consequently waste the investment, the lazy do not put in effort and see their investment wither away, and the dishonest steal the money or extract excessive private benefits from the firm.

4. In a more detailed model, we could motivate debt as a way of extracting cash from entrepreneurs, as for example in Hart and Moore [1989], or the optimal contract in a costly state verification setting as in Diamond [1984].

5. See Myers [1977] and Hart and Moore [1989] for a discussion of the difficulties in writing such contingent contracts.

6. The first inequality in (A.S) limits the number of cases we have to examine and does not change the qualitative implications. In a more detailed model, $M$ could be the outcome of a bargaining game.

7. Our model is functionally identical to Becker [1975]. Our competitive credit market is his general training. Our concentrated credit market is his specific training.

8. In other words, the firm borrows short term each period. Clearly, the firm could borrow at date 0 and spread repayments between date 1 and date 2 . Since the discount rate is 0 , this has no effect in the model and is omitted for simplicity. Of course, we allow for the fact that the good entrepreneur may not have enough cash to repay the loan at date 1.

9. Note that the bank has no incentive to forgive debt (so long as expected cash flows are enough to meet the contracted repayments) at date 1 , since there is no moral hazard or adverse selection problem at date 1 . 
10. This is because the rent on the funds lent conditional on the risky project succeeding is $(M-1)\left[\Pi_{18}\right.$ $\left.-\left(R_{1}-D_{1}\right)\right]$ which using (A.1) and (A.2) is easily shown to exceed the rent on the funds lent for continuing the safe project $\left.(M-1) \prod_{1 s}-\left(S_{1}-D_{1}\right)\right]$. This result holds much more generally. All we need for it to go through is that the bank receive a larger amount from projects which have higher NPV (net present value). This would happen if the firm expands and directs more business towards the bank, or if the bank uses its bargaining power to extract some of the additional NPV for itself.

11. The bank cannot commit to lending at date 1 , else the bad entrepreneurs waste even more money. Furthermore, a loan commitment contracted at a high rate will not work as the firm can always decide
not to take it down.

12. Firms involved in the agriculture, forestry, and fishing industry; finance and insurance underwriting; or real estate investment trusts were excluded from the survey. Firms were itutially sent a series of work sheets which listed the financial information which was going to be collected by the questionnaire. The work sheets were followed up by a telephone interview.

13. We classify commercial banks, savings and loans associations, savings banks and credit unions as banks. Finance companies, insurance companies, brokerage or mutual fund companies, leasing companies and mortgage banks are classified as non bank financial institutions. We also have loans made by non-financial furms. The remaining loans consist of venture capitalist loans (surprisingly few), loans from government agencies and otherwise unclassified loans.

14. Hannan provides evidence that the market for bank commercial loans is local in nature specifying which market the firm is in helps explain the rate charged. The unit of describing markets in his study is the Metropolitan Statistical Area. In our study, the unit can either be the Metropolitan Statistical Area or the county.

15. We are assuming stationarity of the survival process so that we can indeed draw correct inferences about changes in borrowing and interest rates with age from a cross-sectional sample. This assumption is not required when we test differences across markets holding age constant.

16. When we consider only firms which have obtained institutional finaning the differences seem to widen. The mean size of such firms in most competitive markets is almost twice the size of such firms in the most concentrated markets $(\$ 1,444,327$ in competitive markets and $\$ 768,868$ in concentrated markets) and the difference is significant at the 5 percent level. The medians are also different, $\$ 170,000$ versus $\$ 149,000$, and this difference is significant at the 10 percent level. The mean operating profit to asset ratio is higher in the competitive market $(0.58$ versus 0.42$)$ while the mean sales growth is also somewhat higher $(0.34$ versus 0.30 ) despite the fact that the firms in the competitive credit market are larger.

17. Clearly, the annualized rate is not that high if firms are allowed to stretch repayments beyond the due date. Conversely, it may be much higher if firms miss the discount but pay before the due date. Since the stated terms in an industry may differ from actual industry practice, Petersen and Rajan (1994) construct empirical measures of the actual period for which firms can borrow if they do not avail of discounts. To estimate the potential stretch available to trade credit borrowers, they calculate the difference in the DPO between firms that regularly take the early payment discounts and those that do not. For each industry, they determine the median DPO for firms that take less than 10 percent of the discounts they are offered and the median DPO for firms that take more than 90 percent of the discounts 
offered. The difference between these two numbers is an estimate of how long firms that do not take discounts stretch out their payments. For the retail industry it is 8.9 days. Based on the standard terms, firms that do not take the discount are paying an additional 2 percent for 8.9 days of credit, which translates to an annualized interest rate of 123 percent.

18. Why do trade creditors lend when financial institutions are reluctant to lend? Trade creditors may have a better ability to dispose of the collateral, greater incentives related to the margins they make on the product they are selling, greater leverage over the firm because of their ability to cut off supplies, or greater information about the firm [see Mian and Smith 1992]. Trade credit is presurmably very expensive because firms are not in the business of lending, though this merits further research.

19. As of June 1986, there were five remaining unit banking states: Colorado, Kansas, Montana, North Dakota, and Wyoming. Texas was a unit banking state till 1985.

20. Some states limit branch banking without having unit banking laws. If we expand our indicator variable to include states with limits on branching, the banking law coefficient rises from 9.4 to 12.9 . The coefficient on the Herfindahl index, however, is unchanged.

21. While Table $V$ suggests that the structure of the credit market does influence the availability of credit to firms, it does not suggest that the difference in availability across market structure is substantially different for young and old firms as our model would indicate. As we see from Table II, much of the difference in debt levels across markets is for firms four years or less in age. In a concentrated market, the median (mean) discount taken by such firms is 75 (60). In a competitive market, the median (mean) discount taken by such firms is 50 (52). So the difference in medians is 25 and the difference in means is $\mathbf{8}$. In comparison, consider firms older than 15 years. In a concentrated market, the median (mean) discount taken by such firms is 100 (78.5). In a competitive market, the median (mean) discount taken by such firms is 100 (78.3). So the difference in medians is 0 and the difference in means is 0.2 . While we have increased the power of the test (and the economic difference) by taking more extreme groupings, the difference in availability across market structure for young and old firms is still not statistically significant.

22. The results indicate that as compared to firms in the most competitive market, firms in the most concentrated market pay lower interest rates when young and higher rates when old. One way to verify that this finding is not a result of our functional form is to examine the raw data. The evidence in Table VI confirms our intuition. Another way to check our results is to graph the residuals by age for both the most concentrated and the most competitive markets. When we do this we find no evidence of mispecification.

23. As might be expected given the similar distribution of industries across markets, industry adjustments do not affect these resuls. When we subtract the median value of sales growth for all firms having the same two digit S.I.C. code from the sales growth number and then find means and medians across markets, the differences (or the lack of them) are qualitatively similar. This is true for net profits and gross profits also. We adjust the assets by dividing them by the median in the industry. Again the results are qualitatively similar.

24. The evidence from the Japanese liberalizations seems to support this view. Hoshi, Kashyap and Scharfstein [1990] find that firms with relatively high growth and high Tobin's q reduced their bank ties to borrow from the markets. This suggests that the relatively high quality firms left the banks to borrow 
from the markets. Furthermore, the Economist reports that while banks were initially eager to lend to small firms to replace the business lost to the markets, they were now charging them an exorbitant rate "thus hitting the firms that borrowed at the wrong moment, and crimping their plans for new investment" [The Economist, October 27, 1990, p74].

25. That the sale of an equity stake to the lender helps a firm share surplus with it in times of distress has been put forward as one explanation of how the German universal banking system evolved. According to this view, the current stakes of German banks in large German firms are not part of a carefully planned strategy, but a historic accident. The German banks acquired their stakes when they helped ailing German firms out in the 1920s and 1930s (The Economist, November 16, 1991, p102).

26. Governments do actively restrain competition in the financial sectors in the early stages of a country's growth, though these restraints tend to take on a life of their own. Macrae [1990] has an entertaining description of the operation of the old government-sponsored bank cartels. Meerschwam [1991] describes the product market segmentation in lending implemented by the Meiji Restoration in 1868. Subsequent to the attempts to introduce more competition during the U.S. Occupation after World War Il, government guidance reasserted itself through the Ministry of Finance and the Bank of Japan. $\mathrm{He}$ argues that until the opening up of the bond markets, " specialized financial institutions, operating in well-defined product markets... limited financing alternatives for the various corporations. In addition, a lack of price differentiation among products reduced the incentive for participants to break these relationships."

27. This discussion presupposes that governments have a choice in deciding when to deregulate their financial systems. For some countries like Japan, the decision has been partly forced because large companies went offshore to tap Euromarkets [see Meerschwam 1991, p. 135]. In other countries, the wealthy vested interests set up by cartelization will successfully oppose liberalization. 
Table I

Summary stalistics for firms classified by age and credit market concentration

\begin{tabular}{|c|c|c|c|c|c|c|}
\hline \multirow[b]{2}{*}{ Firm characteristics } & \multicolumn{3}{|c|}{ Young firms } & \multicolumn{3}{|c|}{ Old Firms } \\
\hline & $\begin{array}{l}\text { Most } \\
\text { comperitive }\end{array}$ & $\begin{array}{l}\text { Middle } \\
\text { market }\end{array}$ & $\begin{array}{c}\text { Mosi } \\
\text { concentrated }\end{array}$ & $\begin{array}{l}\text { Most } \\
\text { competitive }\end{array}$ & $\begin{array}{l}\text { Middle } \\
\text { market }\end{array}$ & $\begin{array}{c}\text { Most } \\
\text { concentrated }\end{array}$ \\
\hline $\begin{array}{l}\text { Firm solicited by } \\
\text { financial instititution } \\
\text { during the year ( } 1=y^{\prime} \text { es) }\end{array}$ & $\begin{array}{l}0.32^{10} \\
0.00 \\
(0.46) \\
166\end{array}$ & $\begin{array}{c}0.32 \\
0.00 \\
(0.47) \\
488\end{array}$ & $\begin{array}{c}0.26 \\
0.00 \\
(0.44) \\
966\end{array}$ & $\begin{array}{c}0.46 \\
0.00 \\
(0.50) \\
112\end{array}$ & $\begin{array}{c}0.39 \\
0.00 \\
(0.49) \\
516\end{array}$ & $\begin{array}{c}0.31 \\
0.00 \\
(0.46) \\
972\end{array}$ \\
\hline $\begin{array}{l}\text { Firm size (in } \$ 1000 \mathrm{~s} \text { ) } \\
\text { Book value of assets }\end{array}$ & $\begin{array}{c}863 \\
102 \\
(3247) \\
179\end{array}$ & $\begin{array}{c}1074 \\
108 \\
(7188) \\
517\end{array}$ & $\begin{array}{c}569 \\
103 \\
(1836) \\
1010\end{array}$ & $\begin{array}{c}1296 \\
151 \\
(2722) \\
117\end{array}$ & $\begin{array}{c}1692 \\
207 \\
(5379) \\
554\end{array}$ & $\begin{array}{c}1171 \\
155 \\
(3062) \\
1027\end{array}$ \\
\hline$\frac{\text { Gross profits }}{\text { Assets }}$ & $\begin{array}{c}2.78^{\prime} \\
1.61^{\prime} \\
(2.96) \\
170\end{array}$ & $\begin{array}{c}2.18 \\
1.24 \\
(2.46) \\
491\end{array}$ & $\begin{array}{c}1.88 \\
1.06 \\
(2.21) \\
965\end{array}$ & $\begin{array}{c}2.39^{1} \\
1.36^{\prime} \\
(2.76) \\
114\end{array}$ & $\begin{array}{c}1.95 \\
1.66 \\
(2.31) \\
520\end{array}$ & $\begin{array}{c}1.79 \\
0.97 \\
(2.21) \\
973\end{array}$ \\
\hline$\frac{\text { Operating protits }}{\text { Assets }}$ & $\begin{array}{c}1.14 \\
0.17 \\
(4.84) \\
170\end{array}$ & $\begin{array}{c}1.05 \\
0.18 \\
(5.74) \\
491\end{array}$ & $\begin{array}{c}0.63 \\
0.15 \\
(2.49) \\
965\end{array}$ & $\begin{array}{l}0.61 \\
0.23^{10} \\
(1.19) \\
114\end{array}$ & $\begin{array}{c}0.62 \\
0.14 \\
(1.93) \\
520\end{array}$ & $\begin{array}{c}0.64 \\
0.13 \\
(2.88) \\
973\end{array}$ \\
\hline $\begin{array}{l}\text { Sales growth } \\
(1986-1987)\end{array}$ & $\begin{array}{c}0.30 \\
0.09 \\
(0.98) \\
140\end{array}$ & $\begin{array}{c}0.32 \\
0.10 \\
(0.92) \\
435\end{array}$ & $\begin{array}{c}0.31 \\
0.08 \\
(0.91) \\
843\end{array}$ & $\begin{array}{c}0.15 \\
0.04 \\
(0.63) \\
109\end{array}$ & $\begin{array}{c}0.15 \\
0.05 \\
(0.68) \\
495\end{array}$ & $\begin{array}{c}0.14 \\
0.03 \\
(0.58) \\
934\end{array}$ \\
\hline $\begin{array}{l}\text { Number of instits. Irom } \\
\text { which firm borrows }\end{array}$ & $\begin{array}{c}1.35 \\
1.00 \\
(0.59) \\
99\end{array}$ & $\begin{array}{c}1.40 \\
1.00 \\
(0.62) \\
291\end{array}$ & $\begin{array}{c}1.37 \\
1.00 \\
(0.62) \\
655\end{array}$ & $\begin{array}{c}1.28^{1} \\
1.00 \\
(0.51) \\
71\end{array}$ & $\begin{array}{c}1.36 \\
1.00 \\
(0.65) \\
323\end{array}$ & $\begin{array}{c}1.43 \\
1.00 \\
(0.69) \\
624\end{array}$ \\
\hline $\begin{array}{l}\text { Longest business relation } \\
\text { with financial institution } \\
\text { (in years) }\end{array}$ & $\begin{array}{c}4.10^{1} \\
4.00 \\
(3.09) \\
179\end{array}$ & $\begin{array}{c}4.66 \\
4.00 \\
(2.93) \\
517\end{array}$ & $\begin{array}{r}4.75 \\
4.00 \\
(2.95) \\
1010\end{array}$ & $\begin{array}{l}16.37 \\
15.00 \\
(9.81) \\
117\end{array}$ & $\begin{array}{c}16.42 \\
15.00 \\
(10.60) \\
554\end{array}$ & $\begin{array}{c}17.42 \\
15.00 \\
(11.05) \\
1027\end{array}$ \\
\hline
\end{tabular}


The S.B.A. survey classifies the Metropolitan Statistical Area or councy where the firm is headquartered into three caregories on the basis of the cornmercial bank deposit Herfindahl index of the area. The most competitive markets are index of more than 0.18 . The middle market are than 0.10 . The most concentrated market are those with a Herfindahl Young firms are ten years old (the median age) or less. Old firms are more than ten index is between 0.10 and 0.18 . median, the standard deviation, and the number of observations in each cell. For each variable we rested the equality of

We tested the equality of the medians in the most concentrated and most concentrated and most competitive markets. Sum test. Both tests were done separately for young and significance levels of 10 percent $\left({ }^{10}\right), 5$ percent ( $)$, and 1 percent ('). 
Table Il

Institutional Indebtedness of Small Firms

\begin{tabular}{|c|c|c|c|c|c|c|}
\hline \multirow[b]{2}{*}{$\begin{array}{l}\text { Firm age } \\
\text { (in years) }\end{array}$} & \multicolumn{2}{|c|}{ Most competitive market } & \multicolumn{2}{|c|}{ Middle market } & \multicolumn{2}{|c|}{ Most concentrated market } \\
\hline & $\begin{array}{l}\text { Firms with } \\
\text { instit. debt } \\
\text { Percent } \\
\text { number }\end{array}$ & $\begin{array}{l}\text { Debt } \\
\text { assets } \\
\text { Mean } \\
\text { std dev }\end{array}$ & $\begin{array}{c}\text { Firms with } \\
\text { instit. debt } \\
\text { Percent } \\
\text { number }\end{array}$ & $\begin{array}{l}\text { Debl } \\
\text { assets } \\
\text { Mean } \\
\text { std dev }\end{array}$ & $\begin{array}{l}\text { Firms with } \\
\text { instit. debt } \\
\text { Percent } \\
\text { number }\end{array}$ & $\begin{array}{l}\text { Debs } \\
\text { assets } \\
\text { Mean } \\
\text { std der }\end{array}$ \\
\hline$\leq 2$ & $\begin{array}{c}0.47 \\
12\end{array}$ & $\begin{array}{c}0.49 \\
(0.36)\end{array}$ & $\begin{array}{c}0.49 \\
55\end{array}$ & $\begin{array}{c}0.44 \\
(0.46)\end{array}$ & $\begin{array}{l}0.65 \\
147\end{array}$ & $\begin{array}{c}0.46 \\
(0.38)\end{array}$ \\
\hline $3-4$ & $\begin{array}{c}0.49 \\
20\end{array}$ & $\begin{array}{c}0.44 \\
(0.35)\end{array}$ & $\begin{array}{c}0.60 \\
60\end{array}$ & $\begin{array}{c}0.39 \\
(0.49)\end{array}$ & $\begin{array}{l}0.65 \\
141\end{array}$ & $\begin{array}{c}0.43 \\
(0.30)\end{array}$ \\
\hline $5-6$ & $\begin{array}{c}0.65 \\
\therefore\end{array}$ & $\begin{array}{c}0.28 \\
(0.26)\end{array}$ & $\begin{array}{c}0.55 \\
64\end{array}$ & $\begin{array}{c}0.43 \\
(0.56)\end{array}$ & $\begin{array}{l}0.68 \\
131\end{array}$ & $\begin{array}{c}0.39 \\
(0.36)\end{array}$ \\
\hline $7-8$ & $\begin{array}{c}0.69 \\
20\end{array}$ & $\begin{array}{c}0.19 \\
(0.18)\end{array}$ & $\begin{array}{c}0.63 \\
50\end{array}$ & $\begin{array}{c}0.38 \\
(0.40)\end{array}$ & $\begin{array}{l}0.64 \\
125\end{array}$ & $\begin{array}{c}0.43 \\
(0.43)\end{array}$ \\
\hline $9-10$ & $\begin{array}{c}0.57 \\
17\end{array}$ & $\begin{array}{c}0.32 \\
(0.45)\end{array}$ & $\begin{array}{c}0.60 \\
65\end{array}$ & $\begin{array}{c}0.34 \\
(0.32)\end{array}$ & $\begin{array}{l}0.65 \\
117\end{array}$ & $\begin{array}{c}0.40 \\
(0.34)\end{array}$ \\
\hline $11 \cdot 13$ & $\begin{array}{c}0.70 \\
19\end{array}$ & $\begin{array}{c}0.32 \\
(0.22)\end{array}$ & $\begin{array}{c}0.57 \\
60\end{array}$ & $\begin{array}{c}0.45 \\
(0.37)\end{array}$ & $\begin{array}{r}0.66 \\
142\end{array}$ & $\begin{array}{c}0.38 \\
(0.58)\end{array}$ \\
\hline $14-17$ & $\begin{array}{c}0.59 \\
13\end{array}$ & $\begin{array}{c}0.44 \\
(0.64)\end{array}$ & $\begin{array}{c}0.64 \\
75\end{array}$ & $\begin{array}{c}0.38 \\
(0.48)\end{array}$ & $\begin{array}{r}0.62 \\
146\end{array}$ & $\begin{array}{c}0.33 \\
(0.28)\end{array}$ \\
\hline $18-22$ & $\begin{array}{c}0.75 \\
15\end{array}$ & $\begin{array}{c}0.38 \\
(0.30)\end{array}$ & $\begin{array}{c}0.61 \\
75\end{array}$ & $\begin{array}{c}0.27 \\
(0.22)\end{array}$ & $\begin{array}{l}0.67 \\
126\end{array}$ & $\begin{array}{c}0.34 \\
(0.28)\end{array}$ \\
\hline $23-31$ & $\begin{array}{c}0.63 \\
17\end{array}$ & $\begin{array}{c}0.96 \\
(0.84)\end{array}$ & $\begin{array}{c}0.55 \\
62\end{array}$ & $\begin{array}{c}0.29 \\
(0.24)\end{array}$ & $\begin{array}{l}0.61 \\
123\end{array}$ & $\begin{array}{c}0.33 \\
(0.27)\end{array}$ \\
\hline $\begin{array}{l}\text { Greater } \\
\text { than } 32\end{array}$ & $\begin{array}{c}0.33 \\
7\end{array}$ & $\begin{array}{c}0.24 \\
(0.14)\end{array}$ & $\begin{array}{c}0.57 \\
54\end{array}$ & $\begin{array}{c}0.30 \\
(0.28)\end{array}$ & $\begin{array}{c}0.47 \\
87\end{array}$ & $\begin{array}{c}0.25 \\
(0.24)\end{array}$ \\
\hline
\end{tabular}

Firms are classified by the concentration of the credit markets where the firm is located and by the age of the firm. Firm age is years since acquired by the present owners. The SBA survey classifies the Metropolitan Statistical Area or county where the firm is headquartered into three categories on the basis of the commercial bank deposit Herfindahl index of the area. The most competitive market has a Herfindahl index of less than 0.10, and the most concentrated market has a Herfindahl index of more than 0.18 . The debt to asset ratio includes only debe from institutions in the numerator. Loans from owners and family are not included. 
Table IIl

Trade Credit Usage Across Credit Markets with Differing Degrees of Competition

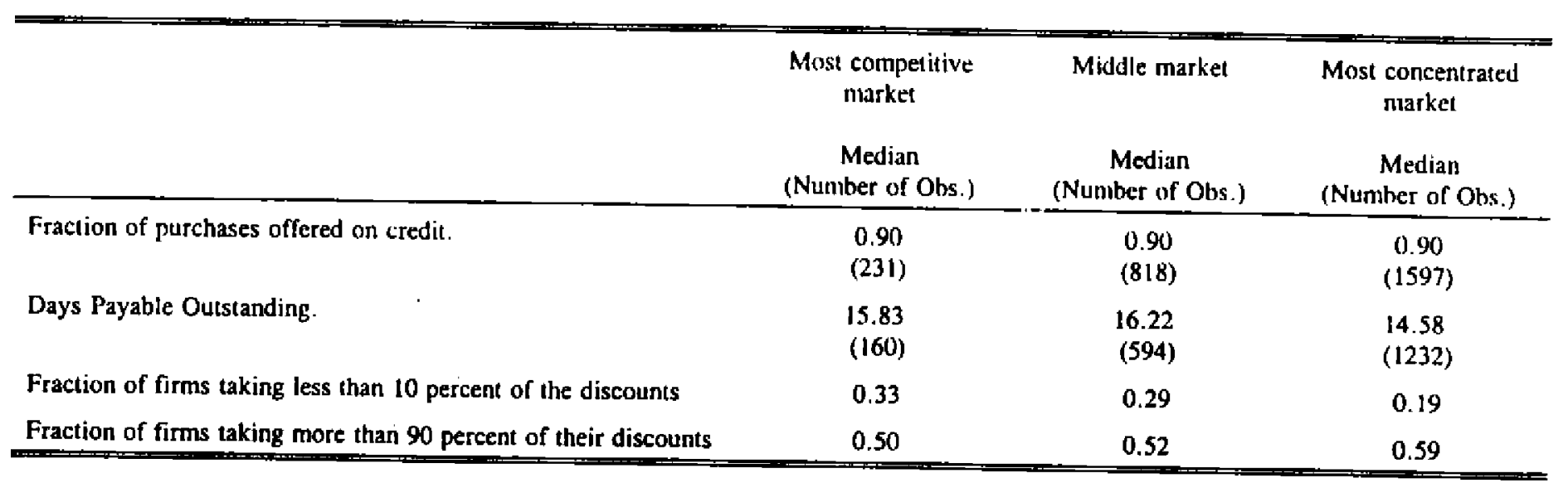

The most competitive market has a Herfindahl index of less than 0.10 , and the most concentrated market has a Herfindahl index of more than 0.18. Days Payable Outstanding is $365^{*}$ Accounts Payable / Cost of Goods Sold. 
Table IV

Credit Availability and the Role of Credit Market Competition

\begin{tabular}{|c|c|c|c|c|}
\hline Independent variable & (1) & (II) & (III) & (IV) \\
\hline \multicolumn{5}{|l|}{ Firm characteristics } \\
\hline Log(book value of assets) & $\begin{array}{r}7.21^{\prime} \\
(1.70)\end{array}$ & $\begin{array}{r}7.26^{1} \\
(1.70)\end{array}$ & $\begin{array}{r}7.10^{1} \\
(1.79)\end{array}$ & $\begin{array}{r}7.13^{\prime} \\
(1.79)\end{array}$ \\
\hline$\frac{\text { Operating Profits }}{\text { Book Assets }}$ & $\begin{array}{r}5.88^{5} \\
(2.79)\end{array}$ & $\begin{array}{r}5.95^{5} \\
(2.80)\end{array}$ & $\begin{array}{l}5.22^{10} \\
(2.82)\end{array}$ & $\begin{array}{l}5.35^{10} \\
(2.84)\end{array}$ \\
\hline Firm is a corporation $(0,1)$ & $\begin{array}{l}-8.96 \\
(5.88)\end{array}$ & $\begin{array}{l}-9.10 \\
(5.89)\end{array}$ & $\begin{array}{c}-10.84^{10} \\
(6.24)\end{array}$ & $\begin{array}{r}-10.54^{10} \\
(6.24)\end{array}$ \\
\hline Log firm age (in years) & $\begin{array}{r}8.69^{1} \\
(3.35)\end{array}$ & $\begin{array}{r}8.74^{\prime} \\
(3.35)\end{array}$ & $\begin{array}{l}10.19^{\prime} \\
(3.73)\end{array}$ & $\begin{array}{l}10.39^{\prime} \\
(3.73)\end{array}$ \\
\hline Firm is locoled in an MSA & $\begin{array}{l}-7.44 \\
(5.45)\end{array}$ & $\begin{array}{l}-6.93 \\
(5.47)\end{array}$ & $\begin{array}{l}-4.32 \\
(5.75)\end{array}$ & $\begin{array}{l}-4.97 \\
(5.78)\end{array}$ \\
\hline Sales growth (1986-1987) & & & $\begin{array}{c}4.40 \\
(3.86)\end{array}$ & $\begin{array}{c}4.41 \\
(3.86)\end{array}$ \\
\hline $\begin{array}{l}\text { Firm is located in a unit banking } \\
\text { state }\end{array}$ & & $\begin{array}{l}9.36 \\
(9.94)\end{array}$ & & \\
\hline \multicolumn{5}{|l|}{ Relationship character istics } \\
\hline $\begin{array}{l}\text { Log(length of longest } \\
\text { relationship) (in years) }\end{array}$ & $\begin{array}{l}18.64^{\prime} \\
(3.84)\end{array}$ & $\begin{array}{r}18.42^{\prime} \\
(3.85)\end{array}$ & $\begin{array}{l}19.70^{\mathrm{d}} \\
(4.05)\end{array}$ & $\begin{array}{l}19.64^{\prime} \\
(4.05)\end{array}$ \\
\hline $\begin{array}{l}\text { Debt from financial scrvice } \\
\text { provider (percent) }\end{array}$ & $\begin{array}{c}2.54 \\
(5.74)\end{array}$ & $\begin{array}{c}2.11 \\
(5.75)\end{array}$ & $\begin{array}{c}3.37 \\
(6.03)\end{array}$ & $\begin{array}{c}3.51 \\
(6.03)\end{array}$ \\
\hline $\begin{array}{l}\text { Number of institutions from } \\
\text { which firm borrows }\end{array}$ & $\begin{array}{r}-11.62^{\prime} \\
(3.16)\end{array}$ & $\begin{array}{r}-11.56^{\prime} \\
(3.16)\end{array}$ & $\begin{array}{r}-11.40^{1} \\
(3.33)\end{array}$ & $\begin{array}{r}-11.35^{\prime} \\
(3.33)\end{array}$ \\
\hline \multicolumn{5}{|l|}{ Financial marker concentration } \\
\hline Herfindahl $>0.18(0,1)$ & $\begin{array}{l}16.54^{1} \\
(5.66)\end{array}$ & $\begin{array}{l}17.21^{1} \\
(5.70)\end{array}$ & $\begin{array}{l}16.87^{\prime} \\
(5.98)\end{array}$ & $\begin{array}{l}19.05^{1} \\
(6.30)\end{array}$ \\
\hline Herfindahl $<0.10(0.1)$ & & & & $\begin{array}{c}11.48 \\
(10.35)\end{array}$ \\
\hline Number of observations & 1459 & 1459 & 1339 & 1339 \\
\hline -Log likelihood & 4120.1 & 4119.7 & 3743.0 & 3742.4 \\
\hline
\end{tabular}

The dependent variable is the percentage of offered early payment discounts taken by the firm. The coefficient estimates are from a cobit regression with two sided censoring. 15 percent of the observations are censored at 0 percent; 45 percent of the observations are censored at 100 percent. Standard errors are in parenthesis. The regression also includes seven industry dummies, three region durmmies, and a constant.

Coefficient is significant at the 1 - percent level.

3 Coefficient is significant at the 5 percent level.

${ }^{10}$ Coefficient is significant at the 10 percent level. 
Table V

Percent of early payment discounts taken classified by firm age and credit market competition

\begin{tabular}{lccc}
\hline Firm characterisrics & $\begin{array}{c}\text { Most } \\
\text { competitive }\end{array}$ & $\begin{array}{c}\text { Middle } \\
\text { market }\end{array}$ & $\begin{array}{c}\text { Most } \\
\text { concentrated }\end{array}$ \\
\hline Firm age $<=10$ years & $53.4^{3}$ & 54.7 & 63.0 \\
& 50.0 & 60.0 & 90.0 \\
& $(44.6)$ & $(44.6)$ & $(41.5)$ \\
& 93 & 290 & 593 \\
Firm 4 ye $>10$ years & $68.4^{10}$ & 67.2 & 76.6 \\
& 100.0 & 95.0 & 100.0 \\
& $(41.7)$ & $(41.5)$ & $(35.9)$ \\
& 69 & 331 & 640 \\
\hline
\end{tabular}

We tested the equality of the mean percent of early payment discounts taken in the most concentrated and most competitive markets. The test is done separately for young (firms less than or equal to ten years old) and old firms (firms greater than ten years old). Differences in the means are noted for significance levels of 10 perceni $\left({ }^{10}\right)$. 5 percent ( ).
and 1 percent ( $)$. 
Table VI

Borrowing Costs Across Market Structures

\begin{tabular}{ccc}
\hline \hline & $\begin{array}{c}\text { Young firms } \\
\text { (Age }<=10 \text { years) }\end{array}$ & $\begin{array}{c}\text { Old firms } \\
\text { (Age > 10 years) }\end{array}$ \\
\hline Wost competitive market & 11.50 & 10.64 \\
(Herfindahl $<0.10)$ & $(2.31)$ & $(2.19)$ \\
& 59 & 48 \\
Most concentrated market & 11.38 & 11.04 \\
(Herfindahl $>0.18$ ) & $(2.34)$ & $(2.36)$ \\
& 477 & 403 \\
\hline
\end{tabular}

The S.B.A. survey classifies the Metropolitan Statistical Area or county where the firm is headquartered into three caregories on the basis of the commercial bank deposit Herfindahl index of the uree. The most competitive markets are those with a value of the Herfindahl index of less than 0.10 . The most concentrated martret are those with a Herfindahl index of more than 0.18 . Young firms are ten years old (the median age) or lest. Old firms are more than ten years old. We report the mean interest rate, the standard deviation, and the number of observations in each cell. 
Table V1l

The Evolution of Borrowing Costs Across Market Structures

\begin{tabular}{|c|c|c|c|}
\hline Independent Variable & $I$ & II & III \\
\hline \multicolumn{4}{|l|}{ Credit Market Conditions } \\
\hline Herfindahl greater than $0.18(0,1)$ & $\begin{array}{l}-1.285^{10} \\
(0.686)\end{array}$ & & $\begin{array}{l}-1.347^{10} \\
(0.690)\end{array}$ \\
\hline Herfindahl between 0.10 and $0.18(0,1)$ & $\begin{array}{l}-1.704^{3} \\
(0.721)\end{array}$ & & $\begin{array}{l}-1.759^{5} \\
(0.724)\end{array}$ \\
\hline $\begin{array}{l}\text { Log of firm age if Hertindahl is } \\
\text { greater than } 0.18\end{array}$ & $\begin{array}{l}-0.154^{10} \\
(0.088)\end{array}$ & & $\begin{array}{l}-0.153^{10} \\
(0.088)\end{array}$ \\
\hline $\begin{array}{l}\text { Log of firm age if Herfindahl is } \\
\text { between } 0.10 \text { and } 0.18\end{array}$ & $\begin{array}{l}-0.135 \\
(0.127)\end{array}$ & & $\begin{array}{l}-0.134 \\
(0.127)\end{array}$ \\
\hline $\begin{array}{l}\text { Log of firm age if Herfindahl is } \\
\text { less than } 0.10\end{array}$ & $\begin{array}{l}-0.725^{\prime} \\
(0.273)\end{array}$ & & $\begin{array}{l}-0.732^{1} \\
(0.273)\end{array}$ \\
\hline Log of firm age if firm is in an MSA & & $\begin{array}{l}-0.240^{9} \\
(0.112)\end{array}$ & \\
\hline Log of firm age if firm is not in an MSA & & $\begin{array}{l}-0.154^{10} \\
(0.090)\end{array}$ & \\
\hline \multicolumn{4}{|l|}{ Interest rate variables } \\
\hline Floating rate loan $(0.1)$ & $\begin{array}{l}-0.47 \gamma^{s} \\
(0.187)\end{array}$ & $\begin{array}{l}-0.459^{5} \\
(0.188)\end{array}$ & $\begin{array}{l}-0.479^{5} \\
(0.187)\end{array}$ \\
\hline Prime rate & $\begin{array}{r}0.278 \\
(0.032)\end{array}$ & $\begin{array}{r}0.272^{\prime} \\
(0.032)\end{array}$ & $\begin{array}{r}0.277^{1} \\
(0.032)\end{array}$ \\
\hline Term structure spread & $\begin{array}{c}0.011 \\
(0.084)\end{array}$ & $\begin{array}{l}0.014 \\
(0.085)\end{array}$ & $\begin{array}{c}0.010 \\
(0.084)\end{array}$ \\
\hline Default spread & $\begin{array}{r}0.357^{3} \\
(0.153)\end{array}$ & $\begin{array}{r}0.364^{9} \\
(0.153)\end{array}$ & $\begin{array}{r}0.352^{3} \\
(0.153)\end{array}$ \\
\hline \multicolumn{4}{|l|}{ Fimm characieristics } \\
\hline Log(Book value of assets) & $\begin{array}{l}-0.295^{\prime} \\
(0.048)\end{array}$ & $\begin{array}{l}-0.301^{\prime} \\
(0.048)\end{array}$ & $\begin{array}{l}-0.295^{3} \\
(0.048)\end{array}$ \\
\hline Total debubook assets & $\begin{array}{l}-0.011 \\
(0.147)\end{array}$ & $\begin{array}{l}-0.024 \\
(0.148)\end{array}$ & $\begin{array}{l}-0.003 \\
(0.148)\end{array}$ \\
\hline Firm is a corporation & $\begin{array}{l}-0.158 \\
(0.145)\end{array}$ & $\begin{array}{l}-0.173 \\
(0.145)\end{array}$ & $\begin{array}{l}-0.159 \\
(0.145)\end{array}$ \\
\hline Number of banks from which firm borrows & $\begin{array}{r}0.379^{1} \\
(0.088)\end{array}$ & $\begin{array}{r}0.378^{3} \\
(0.088)\end{array}$ & $\begin{array}{r}0.377^{1} \\
(0.088)\end{array}$ \\
\hline Firm is in an MSA & $\begin{array}{l}-0.021 \\
(0.138)\end{array}$ & $\begin{array}{c}0.074 \\
(0.343)\end{array}$ & $\begin{array}{l}-0.031 \\
(0.139)\end{array}$ \\
\hline Firm is in a unit banking state & & & $\begin{array}{l}-0.213 \\
(0.244)\end{array}$ \\
\hline Loan is from a bank $(0,1)$ & $\begin{array}{c}0.100 \\
(0.193)\end{array}$ & $\begin{array}{c}0.140 \\
(0.192)\end{array}$ & $\begin{array}{c}0.107 \\
(0.193)\end{array}$ \\
\hline Loan is from a non-financial firm $(0,1)$ & $\begin{array}{l}-1.148^{1} \\
(0.367) \\
\end{array}$ & $\begin{array}{l}-1.140^{\prime} \\
(0.367) \\
\end{array}$ & $\begin{array}{l}-1.144^{\prime} \\
(0.367) \\
\end{array}$ \\
\hline Number of observations & 1277 & 1277 & 1277 \\
\hline Adjusted $\mathrm{R}^{2}$ & 0.160 & 0.154 & 0.159 \\
\hline
\end{tabular}


The raxe quoted on the lirm's most recent loan is the dependent variable. The regression also includes seven induscry dumnies, three regional dummies, six dummy variables for the type of assets with which the loan is collateralized, and an intercept. The prime rate is the rase as the time the loan was made. The term structure spread is the difference between the 10 year government bond yield and the 3 month t-bill yield as the time the loan was made. The default spread is the difference between the BAA corporate bond yield and the 10 year government bond yield at the time the loan was made.

1 Coefficient is significant at the 1 percent level.

s Coefficient is significant as the 5 percent level.

:0 Cofficient is significant at the 10 percent levet. 
Figure 1

\section{Distribution of Industries by Depost Market Concentration}

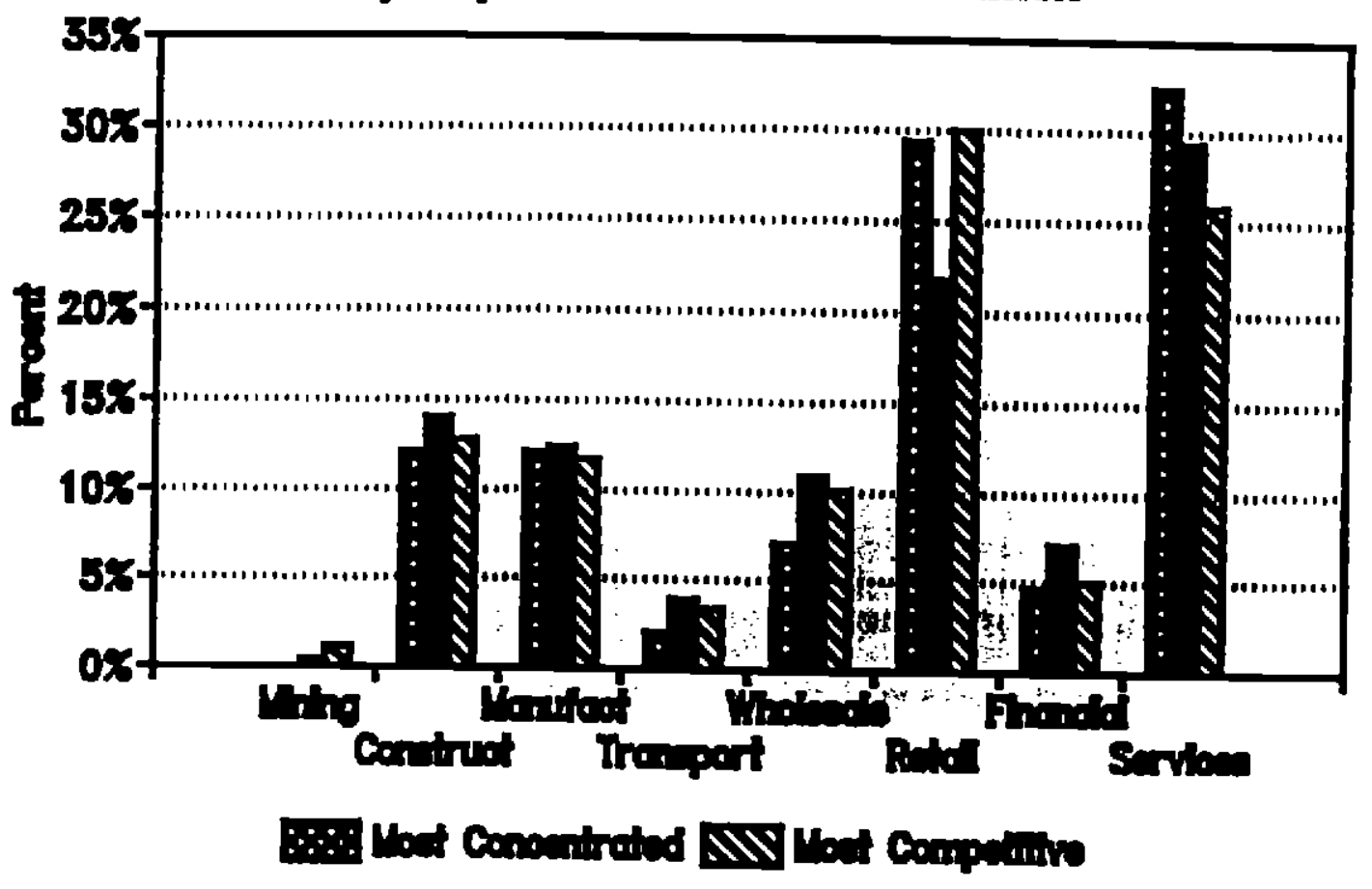

Firms are classified by their one digit SIC code. We graphed the percent of firms in each industry for each of the deposit market concentrations: most competitive (Herfindahl index less than 0.1 ). most concentrated (Herfindahl index greater than 0.18), and the middle market. 
Figure 2

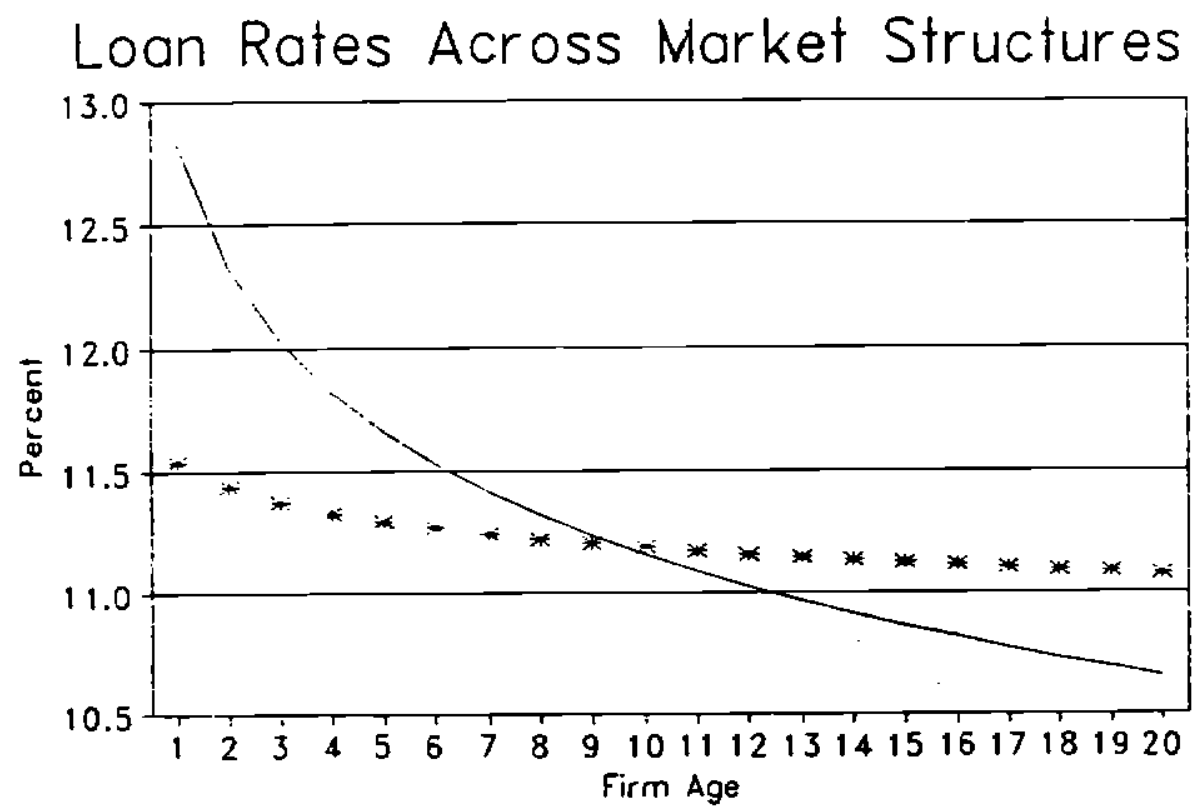

*: Mosl Concentraled - Most Competitive

The loan rales are based on estimates from Table VII. All variables, except the firm's age and the market type (most competitive vs. most concentrated) were set equal to the sample means. The average loan rate in this sample is 11.1 percent. 
To order any of these papers, see instructions at the end of the list. To subscribe to all NBER Working Papers or the papers in a single area, see instructions inside the beck cover. A complete list of NBER Working Papers and Reprints can be accessed on the Internet by using our gopher at nber.harvard.edu.

\begin{tabular}{|c|c|c|c|}
\hline Number & Author(s) & $\underline{\text { Title }}$ & Dale \\
\hline 4865 & $\begin{array}{l}\text { Jeffrey A. Frankel } \\
\text { Andrew K. Rose }\end{array}$ & $\begin{array}{l}\text { A Survey of Empirical Research } \\
\text { on Nominal Exchange Rates }\end{array}$ & $9 / 94$ \\
\hline 4866 & George J. Borjas & $\begin{array}{l}\text { Assimilation and Changes in Cohort Quality } \\
\text { Revisited: What Happened to Immigrant } \\
\text { Eamings in the 1980s? }\end{array}$ & $9 / 94$ \\
\hline 4867 & $\begin{array}{l}\text { Joel Slemrod } \\
\text { Cart Hansen } \\
\text { Roger Procter }\end{array}$ & $\begin{array}{l}\text { The Seesaw Principle in Intemational } \\
\text { Tax Policy }\end{array}$ & $9 / 94$ \\
\hline 4868 & Louis Kaplow & A Note on Subsidizing Gifts & $9 / 94$ \\
\hline 4869 & $\begin{array}{l}\text { Harry Grubert } \\
\text { Joel Slemrod }\end{array}$ & $\begin{array}{l}\text { The Effect of Taxes on Investment and } \\
\text { Income Shifting to Puerto Rico }\end{array}$ & $9 / 94$ \\
\hline 4870 & Dani Rodrik & $\begin{array}{l}\text { What Does the Political Economy Literature } \\
\text { on Trade Policy (Not) Tell Us That We } \\
\text { Ought to Know? }\end{array}$ & $9 / 94$ \\
\hline 4871 & Lars E. O. Svensson & $\begin{array}{l}\text { Estimating and Interpreting Forward } \\
\text { Interest Rales: Sweden 1992-1994 }\end{array}$ & $9 / 94$ \\
\hline 4872 & George J. Borjas & Immigration and Welfare, $1970-1990$ & 9/94 \\
\hline 4873 & $\begin{array}{l}\text { Jose De Gregorio } \\
\text { Federico Sturzenegger }\end{array}$ & $\begin{array}{l}\text { Credit Markets and the Welfare Costs } \\
\text { of Inflation }\end{array}$ & 10,94 \\
\hline 4874 & $\begin{array}{l}\text { Brandice J. Canes } \\
\text { Harvey S. Rosen }\end{array}$ & $\begin{array}{l}\text { Following in Her Footsteps? Wornen's Choices } \\
\text { of College Majors and Faculty Gender Composition }\end{array}$ & 1094 \\
\hline 4875 & $\begin{array}{l}\text { Raghuram G. Rajan } \\
\text { Luigi Zingales }\end{array}$ & $\begin{array}{l}\text { What Do We Know about Capital Structure? } \\
\text { Some Evidence from Intemational Data }\end{array}$ & 1094 \\
\hline 4876 & $\begin{array}{l}\text { Gene Grossman } \\
\text { Elhanan Helpman }\end{array}$ & Foreign Investment with Endogenous Prolection & $10 / 94$ \\
\hline 4877 & $\begin{array}{l}\text { Gene Grossman } \\
\text { Elhanan Helpman }\end{array}$ & $\begin{array}{l}\text { Electoral Competition and Special Interest } \\
\text { Politics }\end{array}$ & 1094 \\
\hline 4878 & $\begin{array}{l}\text { C. Keith Head } \\
\text { John C. Ries } \\
\text { Deborah L. Swenson }\end{array}$ & $\begin{array}{l}\text { The Attraction of Foreign Manufacturing } \\
\text { Investments: Investment Promotion and } \\
\text { Agglomeration Economies }\end{array}$ & 10,94 \\
\hline 4879 & David M. Cutler & Market Failure in Small Group Health Insurance & 10,94 \\
\hline
\end{tabular}


To arder any of these papers, see instructions at the end of the list. To subscribe to all NBER Working Papers or the papers in a single area, see instructions inside the back cover. A complete list of NBER Working Papers and Reprints can be accessed on the Internet by using our gopher at nber.harvardedu.

Number
Aulhor(s)

Douglas Hollz-Eakin

John R. Penrod

Harvey S. Rosen

Nouricl Roubini Gian Maria Milesi-Ferretti

Nouriel Roubini Gian Maria Milesi-Ferretti

Raquel Femandez Richard Rogerson

R. Glenn Hubbard Jonathan Skinner Stephen P. Zeldes

Martin Feldstein

Oliver Hart

John Moore

Ricardo J. Caballero Eduardo M.R.A. Engel

Martin Feldstein James H. Stock

Mark Hooker Michael Knetter

John R. Graham Campbell R, Harvey

W. Kip Viscusi

Alan M. Taylor

Maurice Obstfeld Kenneth Rogoff

Michael M. Knetter
Tille

Date

Health Insurance and the Supply of

10,94

Entrepreneurs

Taxation and Endogenous Growth in Open

10,94

Economies

Optimal Taxation of Human and Physical Capital 10/94 in Endogenous Growth Models

Public Education and Income Distribution: A 10,94 Quantitative Evaluation of Education Finance Reform

Precautionary Saving and Social Insurance

$10 / 94$

Fiscal Policies, Capital Fomation and Capitalism 10,94

Debt and Seniority: An Analysis of the Role of Hard Claims in Constraining Management

Explaining Investment Dynamics in U.S.

Manufacturing: A Generalized (S,S) Approach

Measuring Money Growth When Financial

$10 / 94$

Markets Are Changing

Unemployment Effects of Military Spending:

$10 / 94$

Evidence from a Panel of States

Market Timing Ability and Volatility

10,94

Implied in Investment Newsletters'

Asset Allocation Rocommendations

Cigarette Taxation and the Social

10994

Consequences of Smoking

Domestic Saving and International

$10 / 94$

Capital Flows Reconsidered

The Intertemporal Approach to the

$10 / 94$ Current Account

Why Are Retail Prices in Japan So High?: 1094 
To order any of these papers, see instructions at the end of the list. To subseribe to all NBER Working Papers or the papers in a single aren, see instructions inside the back cover. A complete list of NBER Working Papers and Reprints can be accessed on the Internet by using our gopher at nber.harvand edu.

\begin{tabular}{|c|c|}
\hline Number & Author(s) \\
\hline 4895 & Peter Diamond \\
\hline 4896 & Lawrence H. Goulder \\
\hline 4897 & $\begin{array}{l}\text { A. Lans Bovenberg } \\
\text { Lawrence H. Goulder }\end{array}$ \\
\hline 4898 & $\begin{array}{l}\text { Barry Eichengreen } \\
\text { Andrew K. Rose } \\
\text { Charles Wyplosz }\end{array}$ \\
\hline 4899 & Shane Greenstein \\
\hline 4900 & $\begin{array}{l}\text { Orazio P. Attanasio } \\
\text { Thomas C. Delcire }\end{array}$ \\
\hline 4901 & $\begin{array}{l}\text { Timothy F. Bresnahan } \\
\text { Shane Greenstein }\end{array}$ \\
\hline 4902 & Joel Slemrod \\
\hline 4903 & $\begin{array}{l}\text { Assaf Razin } \\
\text { Efraim Sadka }\end{array}$ \\
\hline 4904 & $\begin{array}{l}\text { Emst R. Berndt } \\
\text { Linda Bui } \\
\text { David Reiley } \\
\text { Glen Urban }\end{array}$ \\
\hline 4905 & $\begin{array}{l}\text { Thomas C. Kinnaman } \\
\text { Don Fullerton }\end{array}$ \\
\hline
\end{tabular}

$4906 \quad$ Daniel S. Hamermesh

$4907 \quad$ Kooyul Jung Yong-Cheol Kim René M. Stulz

Tille

Date

Insulation of Pensions from Political Risk

Environmental Taxation and the "Double Dividend": A Reader's Guide

$10 / 94$

Optimal Environmental Taxation in the Presence $10 / 94$ of Other Taxes: General Equilibrium Analyses

Speculative Attacks on Pegged Exchange Rates:

$10 / 94$ An Empirical Exploration with Special Reference to the European Monetary System

From Superminis to Supercomputers: Estimating Surplus in the Computing Market

10,94

IRAs and Household Saving Revisited:

Some New Evidence

1094

The Competitive Crash in Large-Scale

Commencial Computing

1094

Free Trade Taxation and Protectionist Taxation 1094

Resisting Migration: The Problems of Wage $\quad 10,94$

Rigidity and the Social Burden

The Roles of Marketing, Product Quality and 10,94

Price Competition in the Growth and

Composition of the U.S. Anti-Ulcer

Drug Industry

How a Fee Per-Unit Garbage Affects

Aggregate Recycling in a Model with

$10 / 94$

Heterogeneous Households

Aging and Productivity, Rationality and

1094

Malching: Evidence from Economists

Investment Opportunities, Managerial

1094

Discretion, and the Security Issue

Decision

$4908 \quad$ Jun-Koo Kang

René M. Stulz

How Different is Japanese Corporate

Finance? An Investigation of the

$10 / 94$

Informalion Content of New Security issues

Robert J. Barro

Democracy and Growth 
To order any of these papers, see instructions at the end of the list. To subscribe to all NBER Working Papers or the papers in a single area, see instructions inside the back cover. A complete list of NBER Working Papers and Reprints can be accessed on the Internet by using our gopher at nber.harvardedu.

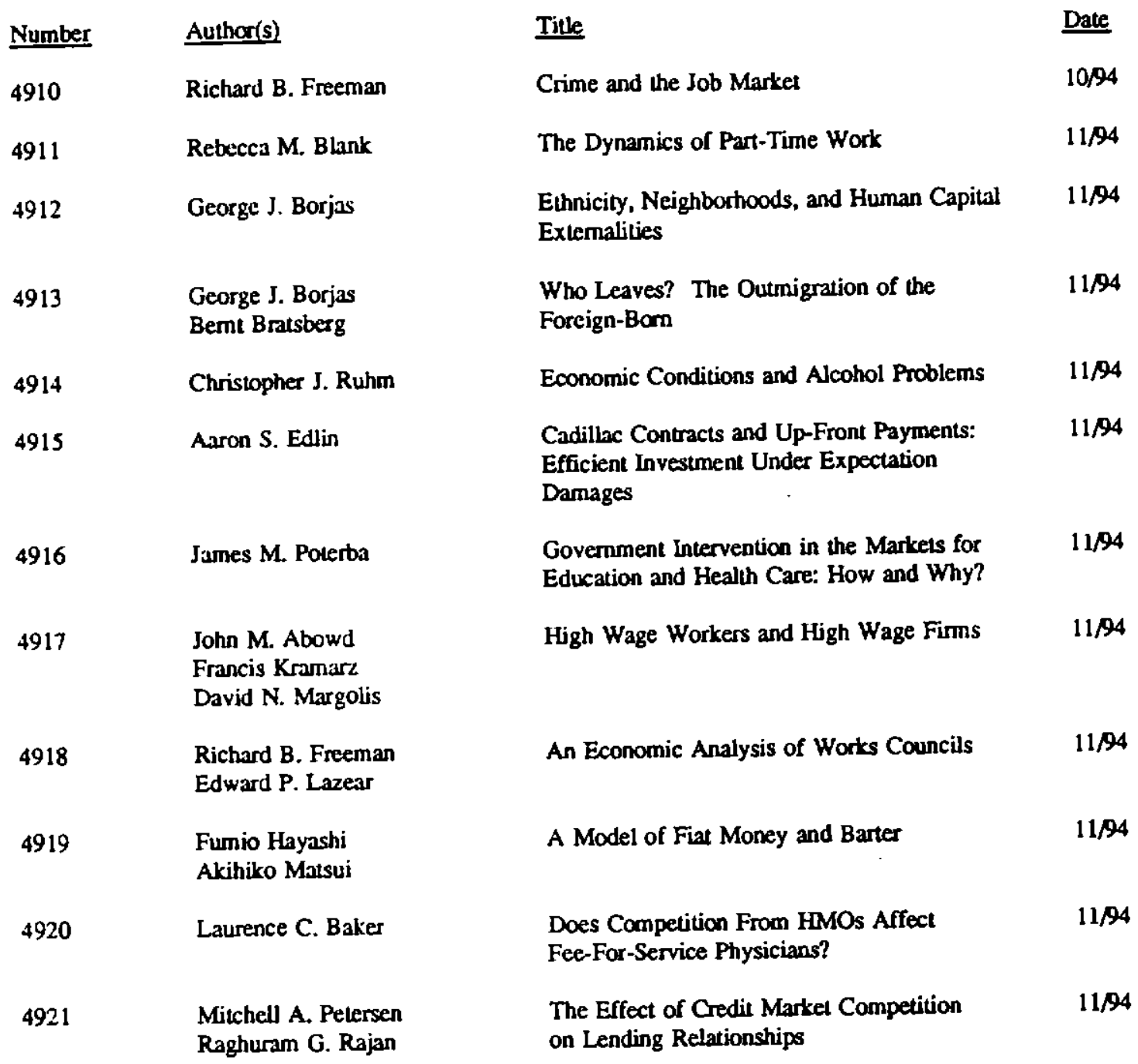

Copies of the above working papers can be oblained by sending $\$ 5.00$ per copy (plus $\$ 10.00$ per order for postage and handling for all locations outside the continental U.S.) to Working Papers, NBER, 1050 Massachusetis Avenue, Cambridge, MA 02138-5398. Advance payment is required on all orders. Payment may be made by check or credit card. Checks should be made payable to the NBER and must be in dollars drawn on a U.S. bank. If paying by credit card, include the cardholder's nane, account number and expiration date. For all mail orders. please be sure to include your retun address and telephone number. Working papers may also be ordered by telephone (617-868-3900), or by fax (617-868-2742). 


\section{National Bureau of Economic Research}

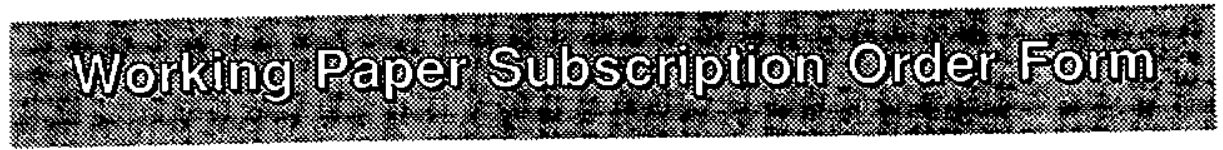

\begin{tabular}{|c|c|c|c|c|}
\hline & \multicolumn{2}{|c|}{ Domestic } & \multicolumn{2}{|c|}{ Foreign"* } \\
\hline & Standard & $\begin{array}{l}\text { Academic Libraries/ } \\
\text { Faculty Members }\end{array}$ & Standard & $\begin{array}{l}\text { Academic Libraries/ } \\
\text { Faculty Members }\end{array}$ \\
\hline 口 Full subscriptions" & $\$ 1300$ & $\$ 650$ & $\$ 1625$ & $\$ 975$ \\
\hline $\begin{array}{l}\text { Partial subscriptions } \\
\square \text { Comorate Fnance } \\
\square \text { Stocks, Bonds, and Foreign Cumency } \\
\square \text { International Finance and Macroeconomics } \\
\square \text { Intemational Trade and Investment } \\
\square \text { Monetary Economics } \\
\square \text { Economic Fluctuations } \\
\square \text { Long-Run Economic Growth } \\
\square \text { Sources of Productivity Growth } \\
\square \text { Taxation } \\
\square \text { Labor Studies } \\
\square \text { Economics of Health and Health Care } \\
\square \text { Economics of the Elderly } \\
\square \text { Inctustrial Organization }\end{array}$ & $\begin{array}{r}300 \\
300 \\
270 \\
270 \\
150 \\
270 \\
150 \\
70 \\
270 \\
270 \\
150 \\
70 \\
70\end{array}$ & $\begin{array}{r}75 \\
75 \\
135 \\
135 \\
75 \\
135 \\
75 \\
35 \\
135 \\
135 \\
75 \\
35 \\
35\end{array}$ & $\begin{array}{r}350 \\
350 \\
350 \\
350 \\
200 \\
350 \\
200 \\
85 \\
350 \\
350 \\
200 \\
85 \\
85\end{array}$ & $\begin{array}{r}110 \\
110 \\
210 \\
210 \\
110 \\
210 \\
110 \\
50 \\
210 \\
210 \\
110 \\
50 \\
50\end{array}$ \\
\hline $\begin{array}{l}\text { Technical Working Papers } \\
\text { [ Historical Development of the American Econor }\end{array}$ & $\begin{array}{l}70 \\
70\end{array}$ & $\begin{array}{l}35 \\
35\end{array}$ & $\begin{array}{l}85 \\
85\end{array}$ & $\begin{array}{l}50 \\
50\end{array}$ \\
\hline \multicolumn{5}{|c|}{$\begin{array}{l}\text { - A full subscription includes all topics listed under "partial subscriptions" except for Technical Working Papers and papers } \\
\text { on the Historical Development of the American Economy. These must be ordered in addition to the tull subscription. }\end{array}$} \\
\hline - Please inquire about subscriplion prices for Afric & an and au & stralla. & & \\
\hline
\end{tabular}

\section{PAYMENT OPTIONS}

YES! Please begin my subscription to the NBER Working Paper Series. I have indicated above which papers I would ike to receive.

By Phone: (617) 868-3900

By FAX: (617) 868-2742

By Mail: Publications Department 1050 Massachusetts Ave.

$\square$ Payment in the amount of
$\square$ Please charge my: $\square$ VISA $\square$ Mastercard

$\square$ Payment in the amount of
Please charge my: $\square$ VISA $\square$ MasterCard Please mail my papers to this address:

Name

Address

Card Number:

Card expiration:

Phone:

FAX:

Signature: 